Journal of Information System, Informatics and Computing

Website/URL: http://journal.stmikjayakarta.ac.id/index.php/jisicom

Email: jisicom@stmikjayakarta.ac.id , jisicom2017@gmail.com

\title{
SISTEM PEMINJAMAN DAN PENGEMBALIAN BUKU PERPUSTAKAAN KELILING BERBASIS WEB MENGGUNAKAN ALGORITMA STRING MATCHING PADA SUKU DINAS PERPUSTAKAAN DAN KEARSIPAN KOTA ADMINISTRASI JAKARTA UTARA
}

\author{
Rendi Sukmawan ${ }^{1}$, Usman Gultom ${ }^{2}$, Rachmawaty \\ Haroen $^{3}$, Verd Yasin ${ }^{4}$ \\ Program Studi Teknik Informatika ${ }^{1}$, \\ Program Studi Teknik Informatika ${ }^{2}$, \\ Program Studi Sistem Informasi ${ }^{3}$, \\ Program Studi Teknik Informatika ${ }^{4}$ \\ Sekolah Tinggi Manajemen Informatika dan Komputer Jayakarta, ${ }^{1,2,3,4}$ \\ 16574009@stmik.jayakarta.ac.id ${ }^{1}$, krinamlindak@ gmail.com ${ }^{2}$, \\ rachmawatyharoen@gmail.com ${ }^{3}$, rachmawatyharoen@gmail.com ${ }^{4}$
}

Received: February 12, 2021. Revised: March 10, 2021. Accepted: April 22, 2021. Published: June 20, 2021. Issue Period: Vol.5 No.1 (2021), Pp.144-173

\begin{abstract}
Abstrak: Perpustakaan Keliling pada Suku Dinas Perpustakaan Dan Kearsipan Kota Administrasi Jakarta Utara merupakan perpustakaan keliling yang bergerak dibidang pembelajaran untuk meningkatkan minat pembaca, khususnya dalam hal pembelajaran. Dimana dalam proses pinjam dan kembali buku dalam perpustakaan keliling masih belum terkomputerisasi dengan baik dan sebagian peroses masih dilakukan dengan tulis tangan dan disimpan dalam buku katalog. Sehingga data-data yang tidak teroganisir sulit dicari, sering hilang dan menyulitkan pengurus dalam pembuatan laporan. Dari permasalahan yang ada penulis merancang dan membangun sistem informasi perpustakaan keliling yang diharapkan dapat menangani permasalahan tersebut. Dalam mencari kebutuhan, pengembangan sistem dilakukan melalui metode pengumpulan data dengan observasi. Pada metode pengembangan sistem, penulis menggunakan metode pengembangan berorientasi objek dengan tools menggunakan Unified Modeling Language (UML) pada system analysis and design.. Peneliti menggunakan bahasa pemrograman PHP dan MYSQL sebagai databasenya. Diharapkan dengan adanya sistem informasi Perpustakaan keliling ini, proses yang terkait dalam peminjaman, dan pengembalian buku menjadi lebih mudah, karena sistem informasi Perpustakaan keliling ini dapat diakses secara multiuser.
\end{abstract}

Kata kunci: Perpustakaan Keliling, Pinjam dan Kembali Buku, Unified Modeling Language (UML), PHP dan MYSQL

\begin{abstract}
The Mobile Library at the North Jakarta Administration City Library and Archives Office is a mobile library engaged in learning to increase readers' interest, especially in terms of learning. Where in the process of borrowing and returning books in the mobile library is still not well computerized and some processes are still done by hand and stored in catalog books. So that unorganized data is difficult to find, is often lost and makes it difficult for administrators to prepare reports. From the existing problems the writer designed and built a mobile library information system which is expected to be able to handle these problems. In looking for needs, system development is carried out through data collection methods by observation. In the system development method, the authors use object-oriented development
\end{abstract}

DOI: $10.52362 /$ jisicom.v5i1.384

Ciptaan disebarluaskan di bawahLisensi Creative Commons Atribusi 4.0 Internasional. 
Journal of Information System, Informatics and Computing

Website/URL: http://journal.stmikjayakarta.ac.id/index.php/jisicom

Email: jisicom@stmikjayakarta.ac.id, jisicom2017@gmail.com

methods with tools using the Unified Modeling Language (UML) in system analysis and design. Researchers use the PHP and MYSQL programming languages as the database. It is hoped that with this mobile library information system, the processes involved in borrowing and returning books will be easier, because this mobile library information system can be accessed multi-user.

Keywords: Mobile Libraries, Borrowing and Returning Books, Unified Modeling Language (UML), PHP and MYSQL.

\section{PENDAHULUAN}

\subsection{Latar Belakang}

Dalam era perkembangan teknologi sekarang ini, informasi peminjaman dan pengembalian buku pada Suku Dinas Perpustakaan dan Kearsipan Kota Administrasi Jakarta Utara merupakan sumber daya yang diharapkan dan harus dikelola secara profesional data secara cepat sesuai waktu yang diharapkan sangatlah dibutuhkan oleh berbagai bidang, diantaranya adalah perpustakaan keliling. Perpustakaan Keliling berfungsi sebagai sarana hasil budaya bangsa dan ilmu pengetahuan teknologi perlu dibina dalam keseluruhan aspeknya.

Kebanyakan orang menganggap bahwa tugas perpustakaan keliling sebagai sarana dokumentasi dan informasi itu adalah hal yang mudah. Sebenarnya bila kita telusuri maka fungsi dan tugas perpustakaan keliling itu sendiri sangat rumit, misalnya untuk mengelompokkan buku sesuai dengan jenisnya, misalnya buku-buku mengenai ilmu pengetahuan alam, ilmu pengetahuan sosial, dan sebagainya. Untuk itu diperlukan teknologi yang mampu menyajikan informasi dan pengolahan data secara cepat dan akurat.

Demikian halnya yang terjadi didalam pencatatan peminjaman dan pengembalian buku pada Suku Dinas Perpustakaan dan Kearsipan Kota Administrasi Jakarta Utara yang masih bersifat manual. Karenanya suatu perusahaasn harus mempunyai suatu sistem yang bisa dipakai untuk mengolah data. Dimana data tersebut digunakan untuk menjadi informasi yang akurat dibutuhkan untuk kemajuan perpustakaan keliling itu sendiri.

Perpustakaan keliling sangat berperan dalam upaya menunjang pembangunan nasional, yaitu meningkatkan pendidikan dan kecerdasan bangsa, disamping itu perpustakaan keliling mempunyai peran penting dalam melestarikan dan mengembangkan kebudayaan dengan koleksi bahan pustaka yang ada agar generasi mendatang dapat mengetahui adanya budaya generasi terdahulu. Oleh karena itu peran serta petugas perpustakaan dan kepala perpustakaan dalam pengolahan perpustakaan sangat penting dalam menentukan optimalnya pelayanan perpustakaan keliling.

Perkembangan teknologi dan pengolahan data masih berjalan dan hal sangat mendukung usaha untuk mengembangkan perpustakaan keliling yang memanfaatkan teknologi komputer, maka penulis mencoba merancang suatu sistem usulan yang bertujuan untuk mempelancar dan mempermudah proses peminjaman dan pengembalian buku pada perpustakaan keliling Suku Dinas Perpustakaan dan Kearsipan Kota Administrasi Jakarta Utara dan diharapkan dengan perancangan sistem ini dapat mengotimalkan pelayanan diperpustakaan.

\subsection{Identifikasi Masalah}

Dari uraian latar belakang masalah diatas, maka dapat diidentifikasikan permasalahan yang melatar belakangi penelitian ini adalah:

1. Proses peminjaman buku-buku diperpustakaan keliling yang berjalan saat ini masih manual, pencatatan masih menggunakan buku besar sehingga menimbulkan kesulitan dalam penyediaan informasi.

2. Belum terciptanya sistem peminjaman buku-buku yang terkomputerisasi.

3. Belum tersedianya media informasi dan media penyimpanan data-data buku yang bisa diakses secara online melalui jaringan internet terhadap sistem pengelolaan data-data buku.

DOI: $10.52362 /$ jisicom.v5i1.384

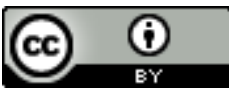

Ciptaan disebarluaskan di bawahLisensi Creative Commons Atribusi 4.0 Internasional. 
Journal of Information System, Informatics and Computing

Website/URL: http://journal.stmikjayakarta.ac.id/index.php/iisicom

Email: jisicom@stmikjayakarta.ac.id , jisicom2017@gmail.com

\subsection{Perumusan Masalah}

Berdasarkan pengidentifikasian masalah di atas dapat dirumuskan permasalahan yang akan diselesaikan dalam penelitian ini adalah :

1. Bagaimana membuat sistem informasi yang dapat mengelola data-data buku yang dapat diakses secara online melalui jaringan internet?

2. Bagaimana membuat media penyimpanan data yang bisa mengelola data data buku?

\subsection{Batasan Masalah}

1. Sistem yang akan dibangun adalah Sistem Informasi Perpustakaan keliling berbasis Web menggunakan metode Algoritma String Matching.

2. Pembangunan sistem ini menggunakan bahasa pemrograman PHP dan MySQL.

3. Sistem yang akan dirancang hanya digunakan untuk Suku Dinas Perpustakaan dan Kearsipan Kota Administrasi Jakarta Utara.

4. Dalam sistem ini hanya membahas mengenai pengolahan data buku, pengelolaan data peminjaman buku, pengelolaan pengembalian buku, pengelolaan data member.

\subsection{Tujuan dan Manfaat dari Penelitian}

\section{Tujuan Penelitian}

1. Untuk mengetahui bagaimana sistem pengolahan data simpan pinjam buku pada Perpustakaan Keliling, Suku Dinas Perpustakaan dan Kearsipan Kota Administrasi Jakarta Utara.

2. Untuk meningkatkan serta mengembangkan sistem pengolahan data Peminjaman dan Pengembalian Buku dari manual ke sistem komputerisasi, sehingga diperoleh sistem yang lebih baik dan menunjang dengan memanfaatkan sumber daya yang ada, baik dari segi perangkat lunaknya (software), perangkat keras (hardware) maupun sumber daya yang ada (brainware).

3. Membuat Aplikasi sistem peminjaman dan pengembalian buku perpustakaan keliling. Guna membantu pelaksanaan peminjaman dan pengembalian buku perpustakaan keliling pada Suku Dinas Perpustakaan dan Kearsipan Kota Administrasi Jakarta Utara.

\section{Manfaat penelitian}

Manfaat penelitian ini diharapkan dapat memberikan manfaat baik secara langsung maupun secara tidak langsung bagi pihak yang berkepentingan adalah sebagai berikut:

\section{1) Bagi Penulis}

Manfaat yang diharapkan dari penelitian ini adalah menambah wawasan dan pengetahuan mengenai pembuatan aplikasi berbasis web dengan menggunakan bahasa pemrograman PHP dan MySql sebagai media informasi pengelolaan data-data buku pada Perpustakaan Keliling Suku Dinas Perpustakaan dan Kearsipan Kota Administrasi Jakarta Utara.

\section{2) Bagi Suku Dinas Perpustakaan dan Kearsipan Kota Administrasi Jakarta Utara}

Manfaat dari penelitian ini bagi Suku Dinas Perpustakaan dan Kearsipan Kota Administrasi Jakarta Utara adalah memberikan sumbangan pikiran dalam penyajian media informasi dalam rangka pendataan data data buku pada Perpustakaan Keliling Suku Dinas Perpustakaan dan Kearsipan Kota Administrasi Jakarta Utara.

\section{3) Bagi Pembaca}

Memberikan gambaran secara umum tentang pembuatan aplikasi Sistem Informasi Pengelolaan data-data Buku pada Perpustakaan Keliling Suku Dinas Perpustakaan dan Kearsipan Kota Administrasi Jakarta Utara.

\section{LANDASAN TEORI}

DOI: $10.52362 /$ jisicom.v5i1.384

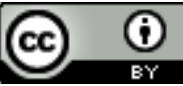

Ciptaan disebarluaskan di bawahLisensi Creative Commons Atribusi 4.0 Internasional. 
Journal of Information System, Informatics and Computing

Website/URL: http://journal.stmikjayakarta.ac.id/index.php/jisicom

Email: jisicom@stmikjayakarta.ac.id , jisicom2017@gmail.com

\subsection{Pengertian Aplikasi}

Menurut (Chan, 2017), aplikasi adalah koleksi window dan objek-objek yang menyediakan fungsi untuk aktivitas user, seperti pemasukan data, proses, dan pelaporan. Aplikasi berasal dari kata application yaitu bentuk benda dari kata kerja to apply yang dalam bahasa Indonesia berarti pengolah. Secara istilah, aplikasi komputer adalah suatu subkelas perangkat lunak komputer yang didukung oleh perangkat lunak sistem dan perangkat keras dalam melakukan proses pengolahan data menjadi informasi. Contoh utama perangkat lunak aplikasi adalah program pengolah kata, lembar kerja, dan pemutar media. Kumpulan aplikasi komputer yang digabung menjadi suatu paket biasanya disebut paket atau suite aplikasi (application suite). Contohnya adalah Microsoft Office dan Open Office.org, yang menggabungkan suatu aplikasi pengolah kata, lembar kerja, serta beberapa aplikasi lainnya. Aplikasi-aplikasi dalam suatu paket biasanya memiliki antarmuka pengguna yang memiliki kesamaan sehingga memudahkan pengguna untuk mempelajari dan menggunakan tiap aplikasi. Umumnya aplikasi-aplikasi tersebut memiliki kemampuan untuk saling berinteraksi sehingga memudahkan serta memberi manfaat yang tinggi bagi pemakai. Contohnya, suatu lembar kerja dapat dimasukkan dalam suatu dokumen pengolah kata walaupun dibuat pada aplikasi lembar kerja yang terpisah.

\subsection{Pengertian Sistem}

Sistem merupakan sebuah tatanan (keterpaduan) yang terdiri atas sejumlah komponen fungsional (dengan satuan fungsi dan tugas khusus) yang saling berhubungan dan secara bersama - sama bertujuan untuk memenuhi suatu proses tertentu. Sistem pada dasarnya adalah sekelompok unsur yang erat hubungannya satu dengan yang lain, yang berfungsi bersama-sama untuk mencapai tujuan tertentu. (Sukamto dan Shalahuddin, 2018: 23).

\subsection{Sistem Informasi}

Menurut (Anggraeni dan Irviani, 2017 : 15) sistem informasi adalah suatu sistem di dalam suatu organisasi yang mempertemukan kebutuhan pengolahan transaksi harian yang mendukung fungsi operasi organisasi yang bersifat manajerial dengan kegiatan strategi dari suatu organisasi untuk dapat menyediakan kepada pihak luar tertentu dengan laporan-laporan yang diperlukan.

\subsection{Flow Map}

Flowmap adalah penggambaran secara grafik dari langkah-langkah dan urut-urutan prosedur dari suatu program.

Flow map merupakan alat bantu yang berguna untuk mempersiapkan alur dokumen dari sebuah program. Bagian ini terdiri dari simbol-simbol yang mewakili fungsi-fungsi tiap langkah program.

\subsection{Konsep Pemodelan Sistem}

$U M L$ mempunyai sejumlah elemen grafis yang bisa dikombinasikan menjadi diagram. Karena ini merupakan sebuah bahasa, $U M L$ mempunyai sejumlah aturan untuk menghubungkan atau mengkombinasikan elemen-elemen tersebut.

\subsection{Flowchart}

Flowchart adalah suatu bagan yang menggambarkan arus logika dari data yang akan diproses dalam suatu program dari awal sampai akhir secara sistematis. Flowchart dapat menunjukkan secara jelas arus pengendalian suatu algoritma, yaitu bagaimana melaksanakan suatu rangkaian kegiatan secara logis dan sistematis.

\subsection{Entity Relationship Diagram (ERD)}

Menurut Rosa A.S dan Shalahuddin (2018:50) ERD, digunakan untuk pemodelan basis data relasional. Entity Relationship Diagram adalah notasi grafis dalam pemodelan data konseptual yang mendeskripsikan hubungan antara penyimpanan untuk memodelkan struktur data dan hubungan antar data.

\subsection{World Wide Web (WWW)}

Menurut Anggraeni dan Irviani (2017:94) World Wide Web merupakan suatu kumpulan informasi pada beberapa server yang terhubung satu sama lain dalam jaringan Internet.

DOI: $10.52362 /$ jisicom.v5i1.384

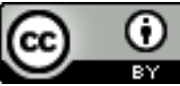

Ciptaan disebarluaskan di bawahLisensi Creative Commons Atribusi 4.0 Internasional. 
Journal of Information System, Informatics and Computing

Website/URL: http://journal.stmikjayakarta.ac.id/index.php/iisicom

Email: jisicom@stmikjayakarta.ac.id, jisicom2017@gmail.com

\subsection{Aplikasi Pemrograman}

Aplikasi pemrograman adalah suatu program yang ditulis atau dibuat untuk melaksanakan tugas khusus dari pengguna atau user.

\subsection{String Macthing}

String macthing adalah pencarian sebuah pattern pada sebuah teks. String macthing digunakan untuk menemukan suatu string yang di sebut dengan pattern dalam string yang di sebut dengan teks. Prinsip kerja algoritma string matching adalah sebagai berikut:

1). Memindai teks dengan bantuan sebuah window yang ukurannya sama dengan panjang pattern.

2). Menempampatkan window pada awal teks.

3). Membandingan karakter pada window dengan karakter dari pattern. Setelah pencocokan dilakukan pergeseran ke kanan pada window. Prosedur ini di lakukan berulang-ulang sampai window berada pada akhir teks. Mekanisme ini di sebut mekanisme sliding window.

\section{Cara kerja String matching}

Cara yang jelas untuk mencari pattern yang cocok dengan teks adalah dengan mencoba mencari di setiap posisi awal dari teks dan mengabaikan pencarian secepat mungkin jika karakter yang salah di temukan. Proses pertama adalah menyelaraskan bagian paling kiri dari pattern dengan teks kemudian di bandingkan karakter yang sesuai dari teks dan pattern setelah seluruhnya cocok maupun tidak cocok dari pattern, window di geser ke kanan sampai posisi (n-m+).

Dengan sebuah nilai karakter $(\mathrm{m}<\mathrm{n})$ yang akan di cari dari teks dalam algoritma pencocokan string, teks di asumsikan berada di dalam memory, sehingga bila kita mencari string di dalam sebuah arsip, maka semua isi arsip perlu di baca terlebih dahulukemudian di simpan di dalam memory. Jika pattern muncul lebih dari sekali di dalam teks, maka pencarian hanya akan memberikan keluaran berupa lokasi pattern di temukan pertama kali (Wulan. 2017).

\subsection{Teknik Pengkodean}

Kode digunakan untuk mengklasifikasikan data, memasukkan data ke dalam komputer dan untuk mengambil bermacam-macam informasi yang berhubungan dengannya. Kode dapat berupa kumpulan angka, huruf dan karakter khusus.

\subsection{Perpustakaan}

\section{Pengertian Perpustakaan}

Menurut Sutarno, (2003:7) "Perpustakaan adalah suatu ruangan, bagian dari gedung/bangunan, atau gedung itu sendiri, yang berisi buku-buku koleksi, yang disusun dan diatur sedemekian rupa sehingga mudah dicari dan dipergunakan apabila sewaktu-waktu diperlukan untuk pembaca".

\section{Unsur-Unsur Perpustakaan}

Yang dimaksud dengan unsur-unsur perpustakaan ialah bagian yang harus ada dalam kegiatan perpustakaan tanpa adanya unsur-unsur tertentu.

Adapun unsur-unsur perpustakaan tersebut adalah sebagai berikut:

a. Wadah atau tempat

Dapat berupa gedung, ruang, lemari buku, rak buku dan sebagainya.

b. Bahan Pustaka

Dapat berupa barang cetakan, misalnya buku, majalah, surat kabar, atlas dan sebagainya. Juga dapat berupa rekaman, misalnya piringan hitam, tape, gambar, lukisan, film dan sebagainya. Disebut juga audio, visual,

DOI: $10.52362 /$ jisicom.v5i1.384

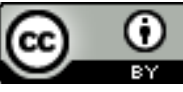

Ciptaan disebarluaskan di bawahLisensi Creative Commons Atribusi 4.0 Internasional. 
Journal of Information System, Informatics and Computing

Website/URL: http://journal.stmikjayakarta.ac.id/index.php/jisicom

Email: jisicom@stmikjayakarta.ac.id, jisicom2017@gmail.com

audio-visual. Audio yaitu alat yang bisa didengar, misalnya piringan hitam tape. Visual yaitu alat yang bisa dipandang atau dilihat, misalnya slide, film, strip, gambar dan sebagainya. Audio visual yaitu alat pandang dengar. Artinya alat yang bisa dilihat dan didengar, misalnya film, video kaset.

c. Disusun menurut sistem tertentu

Maksudnya bahan pustaka disusun menurut cara tertentu agar mudah ditemukan kembali sewaktu-waktu diperlukan. Disinilah banyak menyangkut pekerjaan teknis yang dilakukan oleh mereka yang terdidik dalam hal ini yaitu perpustakaan.

d. Masyarakat pembaca

Mereka terdiri dari berbagai profesi dan lapisan masyarakat. Misalnya petani, buruh, nelayan, pelajar, mahasiswa, dan sebagainya.

e. Guna meningkatkan mutu kehidupan

Ini berarti jika seseorang datang ke perpustakaan apakah untuk menambah pengetahuannya atau mencari informasi atau rekreasi yang positif, atau ingin mempelajari sesuatu hal, diharapkan dapat meningkatkan mutu kehidupan. Artinya bahwa hari ini lebih baik dari kemarin, besok lebih baik dari hari ini.

\section{Koleksi Perpustakaan}

Dari unsur pengertian perpustakaan sebagai koleksi bahan-bahan tertulis, tercetak ataupun grafis lainnya

\subsection{Kerangka Pemikiran}

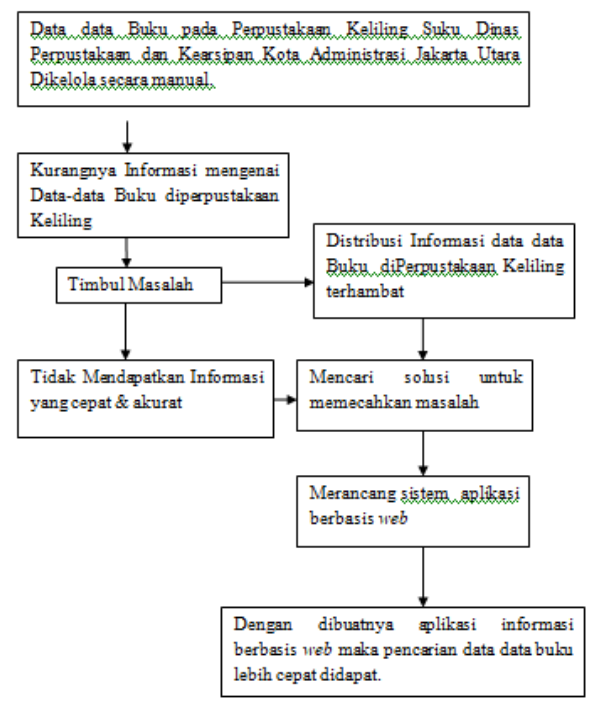

\section{ANALISA SISTEM}

\subsection{Objek Penelitian}

Pada penelitian tugas akhir ini, penulis melakukan penelitian pada Suku Dinas Perpustakaan Dan Kearsipan Kota Administrasi Jakarta Utara, yang beralamat di Jalan Logistik RT 04/004, Kel. Tugu Selatan, Kec. Koja, Kota Jakarta Utara, Daerah Khusus Ibukota Jakarta 14260.

\subsection{Waktu Penelitian}

DOI: $10.52362 /$ jisicom.v5i1.384

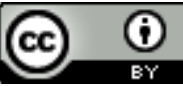

Ciptaan disebarluaskan di bawahLisensi Creative Commons Atribusi 4.0 Internasional. 
Journal of Information System, Informatics and Computing

Website/URL: http://journal.stmikjayakarta.ac.id/index.php/iisicom

Email: jisicom@stmikjayakarta.ac.id , jisicom2017@gmail.com

Penelitian ini dilakukan oleh penulis selama kurun waktu 4 (empat) bulan dari periode bulan September sampai bulan Desember 2020.

Memiliki tahapan-tahapan sebagai berikut :

1. Pengumpulan Data

Pengumpulan data bertujuan untuk memilih data yang diperlukan untuk kebutuhan sistem. Waktu yang di butuhkan untuk mengumpulkan data yaitu satu bulan.

2. Pembuatan Program

Dalam pembuatan program ini waktu yang dibutuhkan satu bulan.

3. Percobaan Program

Percobaan program dilakukan untuk mengetahui apakah semua elemen atau komponen dari sistem program berfungsi dengan baik. Waktu yang diperlukan yaitu selama duaminggu lamanya.

4. Pelatihan Program

Pelatihan program dilakukan untuk memberikan petunjuk atau pengarahan kepada pengguna agar dapat mengoperasikan sistem yang baru dengan baik serta menangani masalah yang timbul. Waktu yang dibutuhkan untuk pelatihan adalah selama dua minggu.

5. Uji Sistem

Pembuatan sistem yang akan diusulkan penulis perlu diuji untuk mengetahui seberapa efektif sistem yang dibuat. Waktu yang dibutuhkan untuk uji sistem ini selama satu bulan.

6. Evaluasi dan Operasional

Bertujuan untuk mengoperasikan sistem baru secara penuh setelah peralihan dari sistem yang telah ada. Selama berlangsungnya sistem baru ini, maka dilakukan evaluasi untuk mengetahui kekurangan dari sistem ini. Waktu yang di butuhkanya itu selama dua minggu.

\subsection{Metode Penelitian Data}

Yang termasuk dalam metode pengumpulan data penelitian yaitu:

\section{1). Analisis Masalah}

Berdasarkan hasil pengamatan pada Suku Dinas Perpustakaan Dan Kearsipan Kota Administrasi Jakarta Utara, didapatkan masalah yaitu proses perpustakaan keliling masih dilakukan secara manual sehingga berkurangnya optimalisasi kinerja pegawai.

Permasalahan yang sedang terjadi di Suku Dinas Perpustakaan Dan Kearsipan Kota Administrasi Jakarta Utaraakan diuraikan secara rincian sebagai berikut :

a. Sistem Perpustakaan Keliling yang ada di Suku Dinas Perpustakaan Dan Kearsipan Kota Administrasi Jakarta Utara masih melakukan mengelola dan mencatat arsip perpustakaan keliling secara manual menggunakan Microsoft Excel sehingga lambatnya proses pemanfaatan arsip buku-buku.

b. Sistem yang ada belum mampu mencari dan mencetak arsip buku-buku yang disimpan dengan cepat.

c. Sistem yang ada belum mampu menata dan menyimpan arsip buku-buku dengan baik.

d. Sistem yang ada belum mampu menindak lanjuti buku yang dipinjam dan buku yang kembali yang masuk ke perpustakaan keliling dengan cepat.

e. Belum adanya sistem untuk mempermudah pegawai dalam mencaridata buku-buku dengan cepat agar pegawai tidak harus mencari secara manual ditempat penyimpanan buku-buku.

2). Observasi

Metoda observasi yakni metoda yang dilakukan dengan cara mengumpulkan data secara langsung ke tempat penelitian dengan mengamati bagaimana sistem yang sedang berjalan.

3). Wawancara

Metoda wawancara yaitu dengan cara melakukan wawancara atau tanya jawab secara langsung kepada staf/pegawai dengan bertatap muka yang bertugas dalam mengelola data kearsipan buku-buku pada Perpustakaan keliling.

4). Studi Pustaka

DOI: $10.52362 /$ jisicom.v5i1.384

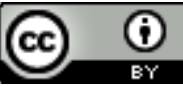

Ciptaan disebarluaskan di bawahLisensi Creative Commons Atribusi 4.0 Internasional. 
Journal of Information System, Informatics and Computing

Website/URL: http://journal.stmikjayakarta.ac.id/index.php/iisicom

Email: jisicom@stmikjayakarta.ac.id, jisicom2017@gmail.com

Teknik pengumpulan data dengan mengumpulkan sumber-sumber tertulis baik dari buku ataupun artikelartikel yang berkaitan dengan masalah yang diteliti, kemudian dipelajari dan dicatat guna memperoleh gambaran secara teoritis sehingga dapat memperkuat pendapat kita mengenai hasil penelitian.

\subsection{Analisa Proses Berjalan}

Dalam membahas sistem berjalan, yang terdiri dari prosedur dalam melakukan berbagai kegiatan dalam penyusunan skripsi pada sistem perpustakaan keliling, penulis melakukan prosedur pada Suku Dinas Perpustakaan Dan Kearsipan Kota Administrasi Jakarta Utarayang akan di jelaskan sebagai berikut:

\section{Proses pendaftaran Anggota}

Masyarakat untuk menjadi anggota harus mengisi formulir pendaftaran yang diberikan oleh petugas perpustakaan, kemudian mengembalikan formulir yang sudah diisikan tersebut kepada petugas perpustakaan, barulah kemudian maysarakat dinyatakan menjadi anggota dan mendapatkan kartu perpustakaan keliling.

\section{Proses peminjaman buku}

Setelah memberikan kartu perpustakaan, anggota diberikan kartu peminjaman buku oleh petugas perpustakaan keliling, kemudian anggota langsung menuju rak-rak buku untuk mendapatkan buku yang diinginkan, buku tersebut dibawa ke petugas perpustakaan untuk diperiksa. Setelah diperiksa, maka diserahkan kembali kartu perpustakaan dan buku perpustakaan yang dipinjam kepada anggota. Kartu peminjaman dan pengembalian disimpan dibuku peminjaman.

\section{Proses pengembalian buku}

Setelah anggota meminjam buku dan ingin mengembalikan buku tersebut, maka anggota langsung bertemu dengan petugas perpustakaan keliling untuk mengembalikan buku tersebut dengan menyerahkan kartu perpustakaan dan beserta buku yang dipinjamnya untuk diperiksa. Setelah diperiksa ternyata semua benar (lengkap) maka kartu anggota diserahkan kembali kepada anggota. Apabila angggota mengembalikan buku lewat pada tanggal yang telah ditentukan maka anggota akan dikenakan sanksi berupa denda. Dan denda tersebut dihitung berdasarkan waktu pengembalian dan waktu peminjaman yang ditetapkan perpustakaaan keliling.

\section{Proses pencatatan laporan}

Pembuatan laporan tersebut dilakukan oleh petugas perpustakaan keliling, terhadap data-data yang diperlukan berdasarkan arsip peminjaman dan buku anggota. Pembuatan laporan tersebut dibuat mengenai laporan tentang jumlah anggota peminjaman dan pengembalian buku yang dibuat dalam periode bulanan lalu diserahkan kepada kepala perpustakaan keliling untuk ditandatangani.

\subsection{Spesifikasi Dokumen Sistem Berjalan}

\section{Spesifikasi Bentuk Dokumen Input}

Sistem informasi perpustkaan keliling pada Suku Dinas Perpustakaan Dan Kearsipan Kota Administrasi Jakarta Utara.Memiliki dua dokumen data masukan ke dalam formulir.

\section{Spesifikasi Bentuk Dokumen Output}

\subsection{FOD (Flow Of Document) Yang Sedang Berjalan}

DOI: $10.52362 /$ jisicom.v5i1.384

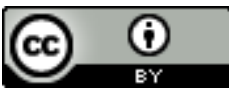

Ciptaan disebarluaskan di bawahLisensi Creative Commons Atribusi 4.0 Internasional. 
Journal of Information System, Informatics and Computing

Website/URL: http://journal.stmikjayakarta.ac.id/index.php/iisicom

Email: jisicom@stmikjayakarta.ac.id, jisicom2017@gmail.com
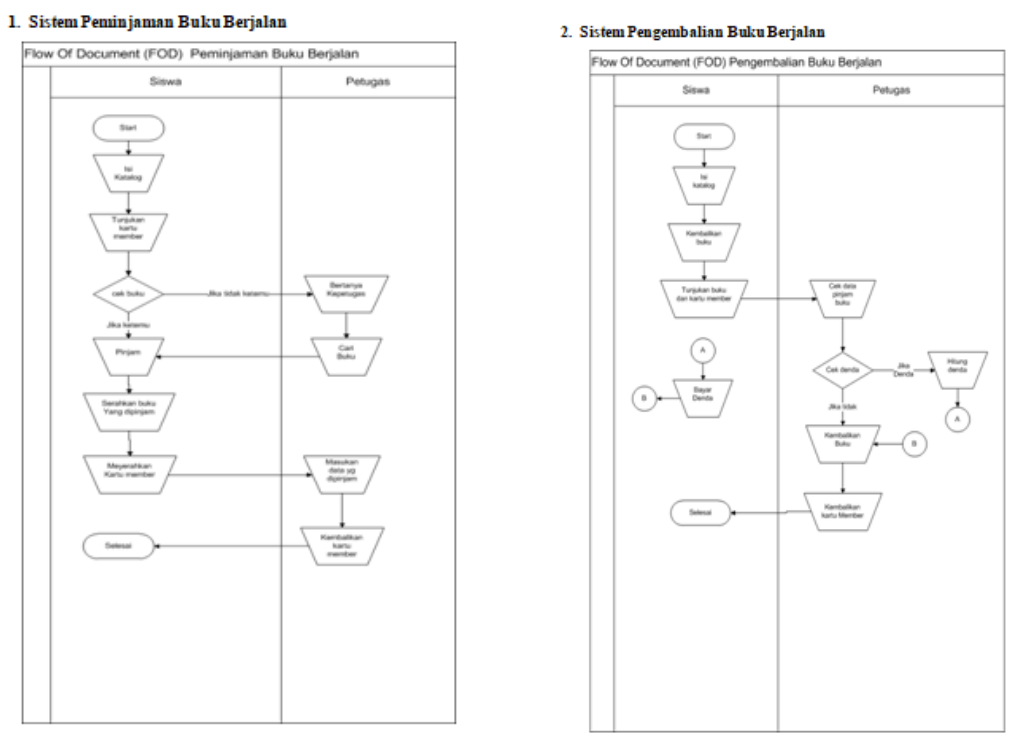

\subsection{Perancangan Sistem}

Perancangan sistem menentukan bagaimana suatu sistem akan menyelesaikan apa yang mesti diselesaikan. Tahap ini menyangkut konfigurasi dari komponen perangkat lunak dan perangkat keras dari suatu sistem sehingga setelah instalasi dari sistem akan benar-benar memuaskan perancangan yang telah ditetapkan pada akhir tahap analisa sistem.

\section{Pemodelan Menggunakan Use Case Diagram}

Use Case Diagram adalah diagram yang terdiri dari suatu proses dan menggambarkan ruang lingkup suatu sistem. Atau sistem secara garis besar di dalam satu lingkaran dan hubungan dengan entitas luar. Diagram konteks dibuat untuk menggambarkan sumber serta tujuan data yang akan diproses atau untuk menggambarkan penggambaran sistem secara global dari keseluruhan sistem yang dijalankan.

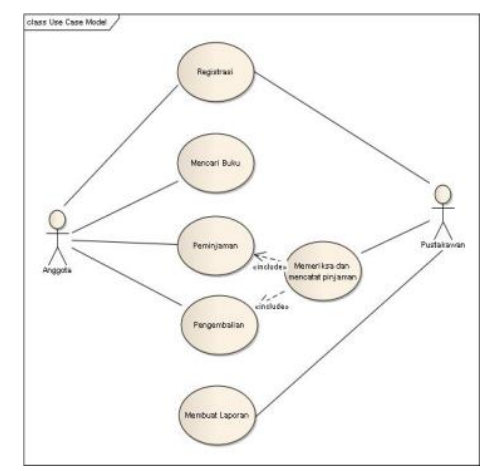

Gambar 3. 1

Keterangan :

Use Case Diagram

\begin{tabular}{|l|l|l|}
\hline No & Aktor & Deskripsi \\
\hline
\end{tabular}

DOI: $10.52362 /$ jisicom.v5i1.384

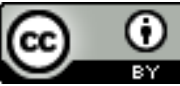

Ciptaan disebarluaskan di bawahLisensi Creative Commons Atribusi 4.0 Internasional. 
Journal of Information System, Informatics and Computing

Website/URL: http://journal.stmikjayakarta.ac.id/index.php/iisicom

Email: jisicom@stmikjayakarta.ac.id, jisicom2017@gmail.com

\begin{tabular}{|l|l|lr|}
\hline 1 & Anggota & $\begin{array}{l}\text { Anggota yang mempunyai } \\
\text { hak untuk melakukan } \\
\text { pinjaman buku }\end{array}$ \\
\hline 2 & Pustakawan & $\begin{array}{l}\text { Pustakawan } \\
\text { mempunyai hak untuk } \\
\text { mengelola seluruh data, } \\
\text { Mencatat, memeriksa, } \\
\text { membuat laporan dan } \\
\text { mempunyai hak akses untuk } \\
\text { membagi informasi. }\end{array}$ \\
\hline
\end{tabular}

\section{Activity Diagram}

Berdasarkan use case maka dapat digambarkan Activity diagram sebagai berikut:

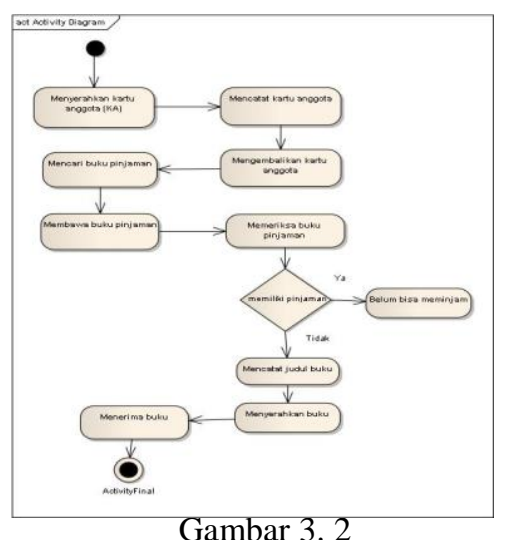

Activity Diagram Peminjaman Buku

Pada gambar 3. 6 menjelaskan mengenai langkah proses peminjaman buku pada perpustakaan keliling yang diawali anggotamenyerahkan kartu anggota (KA) kemudian pustakawan mencatat kartu anggota dan memeriksa pinjaman, jika ada pinjaman anggota tidak dapat meminjam, jika tidak ada pinjaman maka pustakawan mencatat judul buku dan buku diserahkan kepada anggota.

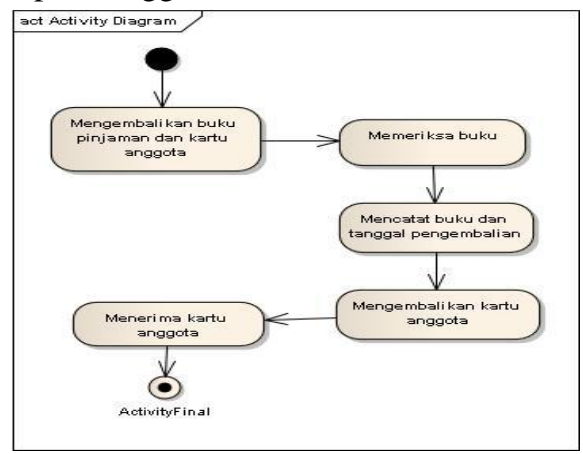

Gambar 3. 3 Activity

Diagram Pengembalian buku

DOI: $10.52362 /$ jisicom.v5i1.384

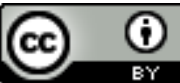

Ciptaan disebarluaskan di bawahLisensi Creative Commons Atribusi 4.0 Internasional. 
Journal of Information System, Informatics and Computing

Website/URL: http://journal.stmikjayakarta.ac.id/index.php/jisicom

Email: jisicom@stmikjayakarta.ac.id, jisicom2017@gmail.com

Pada gambar 3. 7 menjelaskan mengenai langkah proses pengembalian buku pada perpustakaan keliling yang diawali anggota mengembalikan buku pinjaman dan kartu anggota (KA), kemudian pustakawan memeriksa buku, mencatat buku dan tanggal pengembalian kemudian pustakawan mengembalikan kartu anggota kepada anggota.

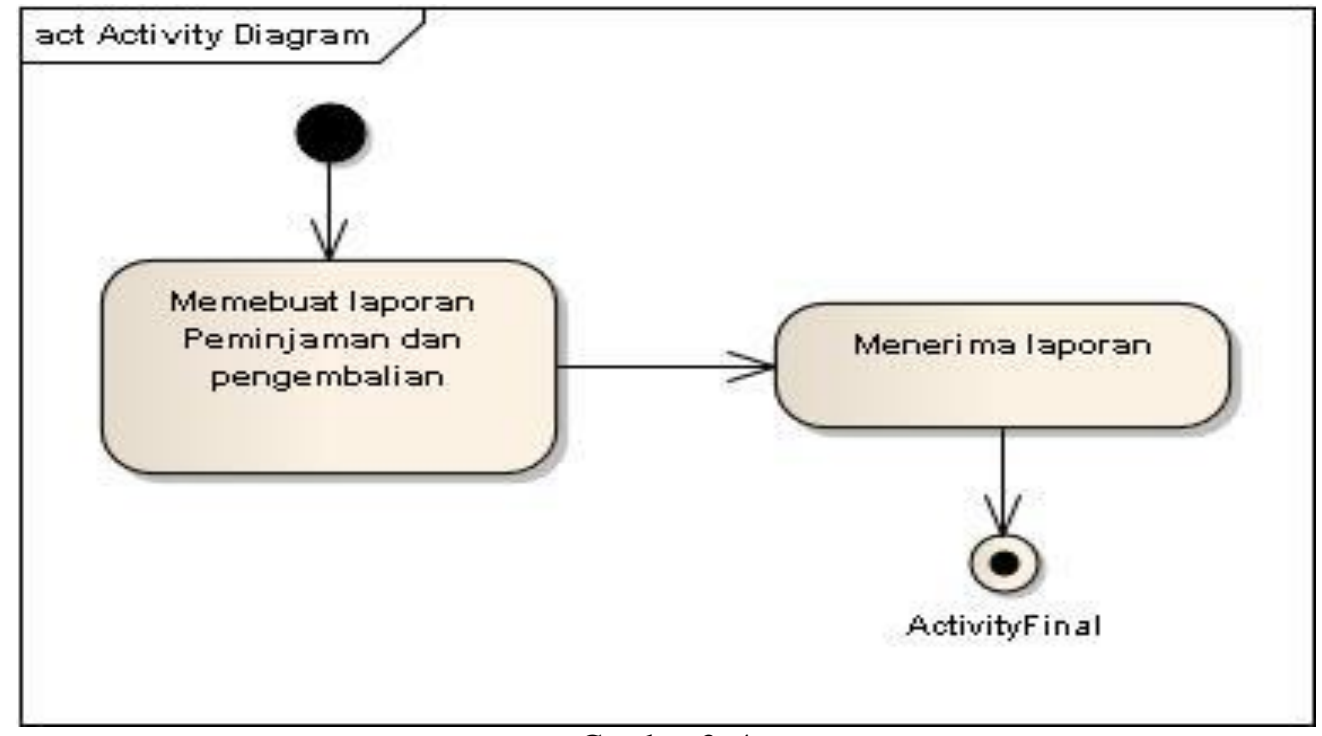

Gambar 3. 4

Activity Diagram Laporan Perpustakaan Keliling

Pada gambar 3. 8 menjelaskan mengenai langkah proses pembuatan laporan peminjaman dan pengembalian buku.

\section{Sequence Diagram}

Diagram sequence biasa digunakan untuk menggambarkan skenario atau rangkaian langkah-langkah yang dilakukan sebagai respons dari sebuah event untuk menghasilkan output tertentu.

DOI: $10.52362 /$ jisicom.v5i1.384

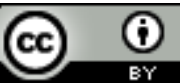

Ciptaan disebarluaskan di bawahLisensi Creative Commons Atribusi 4.0 Internasional. 
Journal of Information System, Informatics and Computing

Website/URL: http://journal.stmikjayakarta.ac.id/index.php/iisicom

Email: jisicom@stmikjayakarta.ac.id, jisicom2017@gmail.com

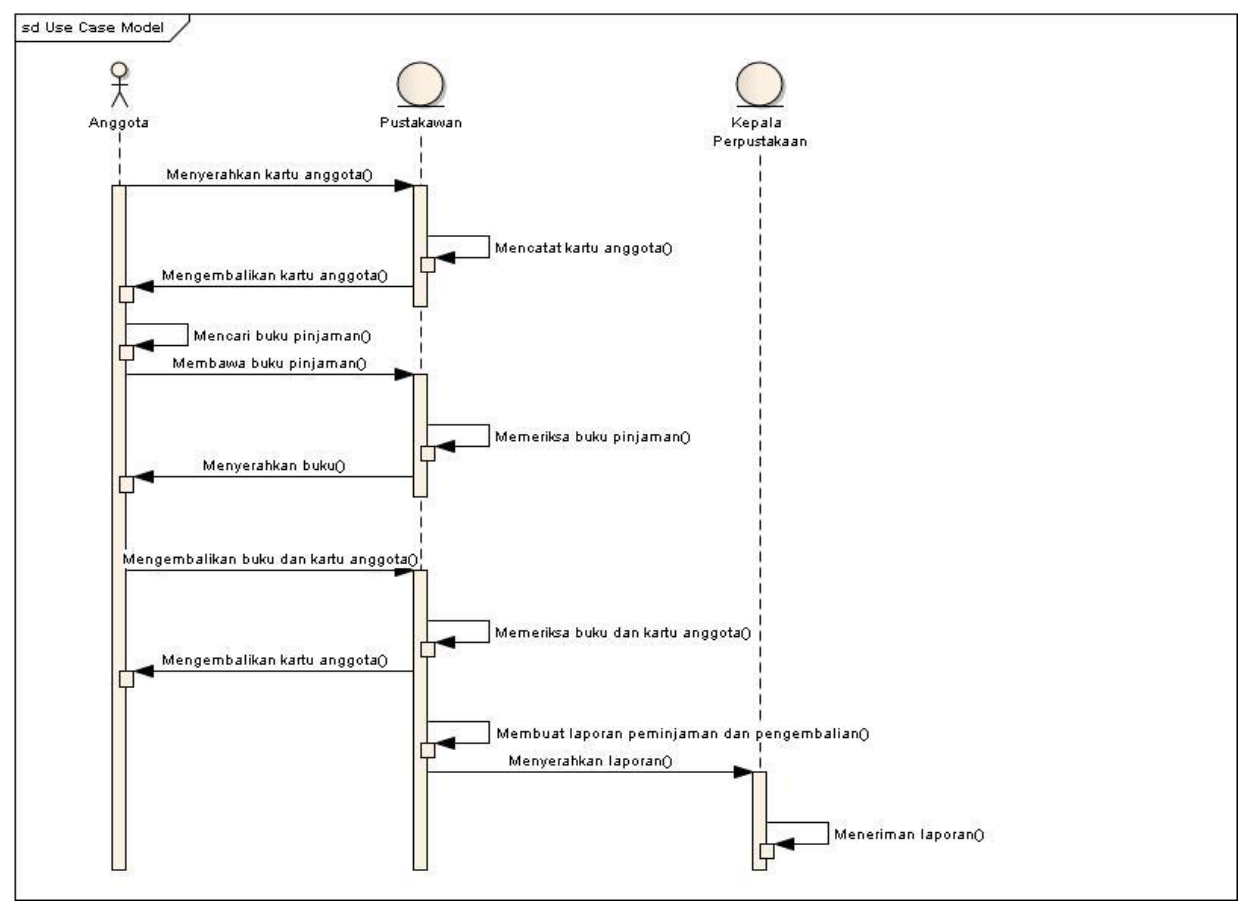

Gambar 3. 5

Sequence Diagram

\subsection{Permasalahan}

Berdasarkan hasil analisa yang dilakukan pada Perpustakaan Keliling pada Suku Dinas Perpustakaan Dan Kearsipan Kota Administrasi Jakarta Utara. Karena sistem yang berjalan masih menggunakan katalog maka timbul beberapa permasalahan seperti :

maka dapat disimpulkan masalah yang dihadapi pada sistem berjalan sebagai berikut :

a) Sistem berjalan ini mengalami kesulitan dalam melakukan pencatatan dan pencarian informasi data buku, data anggota, data peminjaman dan pengembalian buku yang kurang tepat.

b) Sering terjadinya kesalahan pencatatan data dan laporan peminjaman dan pengembalian buku hilang dan buku rusak yang tidak efektif dan efisien, sehingga membutuhkan waktu lama dalam pembuatan laporan.

\subsection{Alternatif Pemecahan Masalah}

Adapun usulan pemecahan masalah untuk memaksimalkan kinerja dari sistem informasi yaitu dengan mengembangkan sistem menjadi berbasis komputerisasi membuatkan Perancangan Sistem Informasi Perpustakaanberbasis web, semua data pemantauan dan pengolahan datanya akan tersimpan ke database sehingga data tidak akan hilang atau rusak dan memudahkan dalam setiap laporannya.sebagai berikut :

a) Fasilitas "Master Data Buku", "Master Data Anggota", "Transaksi Peminjaman”. Fasilitas ini digunakan untuk dapat diketahui informasi mengenai data buku, data anggota dan data peminjaman.

b) Fasilitas “Cetak Laporan”. Fasilitas ini digunakan untuk membuat laporan.

\section{PERANCANGAN DAN IMPLEMENTASI}

\subsection{Analisa Sistem Usulan}

Untuk meningkatkan minat baca dikalangan masyarakat luas khususnya bagi masyarakat dan pentingnya peran serta perpustakaan dalam rangka mencerdaskan kehidupan bangsa dan negara, untuk itu perlu adanya

DOI: $10.52362 /$ jisicom.v5i1.384

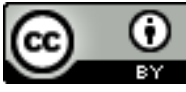

Ciptaan disebarluaskan di bawahLisensi Creative Commons Atribusi 4.0 Internasional. 
Journal of Information System, Informatics and Computing

Website/URL: http://journal.stmikjayakarta.ac.id/index.php/iisicom

Email: jisicom@stmikjayakarta.ac.id , jisicom2017@gmail.com

pembenahan dalam pelayanan perpustakaan. Pada era globalisasi aspek teknologi yang dibutuhkan perannya. Sistem perpustakaan yang masih menggunakan sistem pengolahan manual, tidak efisien dan membutuhkan waktu yang lama dalam pengolahan perpustakaan.

Sistem informasi yang diusulkan memiliki beberapa keunggulan dan perbedaan dari sistem yang sedang berjalan. Sistem

yang diusulkan telah terkomputerisasi dengan baik, lebih mudah digunakan, integritas data terjaga, tidak akan memakan waktu yang lama dalam mengolah data siswa, data buku, data pinjam buku, data kembali buku maupun perhitungan denda. Karena didalamnya telah disediakan pencetakan laporan-laporan dan fasilitas lainnya yang akan memudahkan anggota untuk menggunakan sistem ini.

Dalam sistem usulan ini terdapat prosedur sistem usulan yang tidak jauh berbeda dengan sistem berjalan, disertai dengan pembuatan program perpustakaan.

Dalam penulisan sistem usulan ini juga disertai spesifikasi sistem komputer, dimana akan dijabarkan penggunaan dari perangkat lunak dan perangkat keras serta konfigrasi komputer yang digunakan dalam penerapan perancangan sistem peminjaman buku perpustakaan pada Suku Dinas Perpustakaan dan Kearsipan Kota Administrasi Jakarta Utara.

Dengan adanya penerapan pada sistem usulan ini diharapkan bisa membantu dalam pelayanan perpustakaan yang seefisien mungkin serta dapat menghemat waktu dalam pelayanan informasi yang lebih cepat dan akurat.

\subsection{Prosedur Sistem Usulan}

Perancangan prosedur dari sistem informasi perpustakaan berbasis Web pada Suku Dinas Perpustakaan dan Kearsipan Kota Administrasi Jakarta Utara akan dituangkan dalam bentuk diagram UML. Prosedur yang penulis usulkan adalah sebagai berikut :

\section{Peminjaman buku}

Peminjaman buku masih bersifat membuat form transaksi pinjaman buku Sehingga apabila terdapat kesalahan dalam membuatnya bisa diperbaiki dengan mudah tanpa menimbulkan banyak coretan dan mengganti form baru.

\section{Penghitungan denda}

Penghitungan denda masih bersifat menghitung manual. Membuat form transaksi kembali buku menghitung secara otomatis berdasarkan tanggal tanggal kembali dan tanggal terima. Sehingga apabila terdapat kesalahan dalam membuatnya bisa diperbaiki dengan mudah tanpa menimbulkan banyak coretan dan mengganti form baru.

\section{Pencarian buku}

Pencarian buku yang masih bersifat mencari dengan seksama meminta pertolongan petugas. Membuat form cari buku Sehingga mempermudah dalam pencarian buku yang ingin dipinjam tanpa harus memakan waktu yang lama untuk mencari.

\subsection{UML Sistem Usulan}

\section{Use case Diagram}

Use Case Diagram merupakan permodelan untuk kelakuan (behavior) sistem informasi yang akan dibuat. Dengan Use Case Diagram kita dapat mempresentasikan interaksi antara actor dengan sistem.

\section{Class Diagram}

Class Diagram memiliki 3 area pokok (utama) yaitu : nama, atribut dan operasi. Nama berfungsi untuk memberi identitas pada sebuah kelas, atribut fungsinya adalah untuk memberi karakteristik pada data yang dimiliki suatu objek di dalam kelas, sedangkan operasi fungsinya adalah memberikan sebuah fungsi ke sebuah objek.

\section{Activity Diagram}

Activity diagram menggambarkan berbagai alur aktivitas dalam sistem yang sedang dirancang, bagaimana masing-masing alur berawal, decision yang mungkin terjadi, dan bagaimana mereka berakhir,

\section{Sequence Diagram}

Sequence Diagram menggambarkan serangkaian pesan yang dipertukarkan oleh obyek yang melakukan suatu aksi tertentu. Obyek tersebut diurutkan dari kiri ke kanan, aktor yang menginisiasi interaksi biasanya ditaruh di paling kiri dari diagram.

DOI: $10.52362 /$ jisicom.v5i1.384

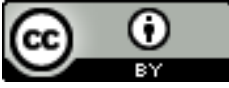

Ciptaan disebarluaskan di bawahLisensi Creative Commons Atribusi 4.0 Internasional. 
Journal of Information System, Informatics and Computing

Website/URL: http://journal.stmikjayakarta.ac.id/index.php/jisicom

Email: jisicom@stmikjayakarta.ac.id, jisicom2017@gmail.com

\section{Perancangan State Chart Diagram}

State chart Diagram menggambarkan transisi dan perubahan keadaan (dari satu state ke state lainnya), pada umumnya state chart diagram menggambarkan class tertentu (satu class dapat memiliki lebih dari satu state chart diagram).

\subsection{Entity Relationship Diagram (ERD)}

Entity relationship diagram digunakan untuk menggambarkan relasi antar tabel dengan tujuan untuk memperjelas hubungan antar table penyimpanan. ERD terdiri dari sekumpulan objek dasar yaitu entitas dan hubungan antar entitas-entitas yang saling berhubungan.

\subsection{Normalisasi}

Entity relationship diagram digunakan untuk menggambarkan relasi antar tabel dengan tujuan untuk memperjelas hubungan antar tabel penyimpanan. ERD terdiri dari sekumpulan objek dasar yaitu entitas dan hubungan antar entitas-entitas yang saling berhubungan.

\subsection{Spesifikasi File}

1. Tabel Admin

$\begin{array}{ll}\text { Nama Tabel } & \text { : Admin } \\ \text { Type File } & \text { : Master } \\ \text { Primary Key } & \text { : nopetuga }\end{array}$

2. Tabel Buku

: nopetugas

\begin{tabular}{|l|l|l|l|}
\hline $\begin{array}{l}\text { Nama } \\
\text { File }\end{array}$ & $\begin{array}{l}\text { Tipe } \\
\text { Data }\end{array}$ & Ukuran & Ket \\
\hline nopetugas & Int & 11 & $\begin{array}{l}\text { Primary } \\
\text { key }\end{array}$ \\
\hline Nama & Var & 30 & \\
\hline username & Var & 30 & \\
\hline password & Var & 30 & \\
\hline level_user & Int & 11 & \\
\hline
\end{tabular}

Nama Tabel

Type File

: Buku

Primary Key

: Master

: kdbuku

\begin{tabular}{|l|l|l|l|}
\hline $\begin{array}{l}\text { Nama } \\
\text { File }\end{array}$ & $\begin{array}{l}\text { Tipe } \\
\text { Data }\end{array}$ & Ukuran & Ket \\
\hline Kdbuku & Var & 15 & Primary \\
\hline Jdbuku & Var & 30 & \\
\hline $\begin{array}{l}\text { Pengaran } \\
\text { g }\end{array}$ & Var & 30 & \\
\hline Penerbit & Var & 30 & \\
\hline
\end{tabular}

DOI: $10.52362 /$ jisicom.v5i1.384

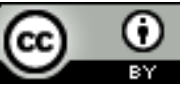

Ciptaan disebarluaskan di bawahLisensi Creative Commons Atribusi 4.0 Internasional. 
e-ISSN : 2597-3673 (Online) , p-ISSN : 2579-5201 (Printed)

Vol.5 No.1, Juni 2021

Journal of Information System, Informatics and Computing

Website/URL: http://journal.stmikjayakarta.ac.id/index.php/iisicom

Email: jisicom@stmikjayakarta.ac.id , jisicom2017@gmail.com

3. Tabel Petugas

Nama Tabel

Type File

Primary ke y

\begin{tabular}{|l|l|l|l|}
\hline Stock & Int & 11 & \\
\hline $\begin{array}{l}\text { Keterang } \\
\text { an }\end{array}$ & Var & 100 & \\
\hline
\end{tabular}

$$
\begin{aligned}
& \text { : petugas } \\
& \text { : Master } \\
& \text { : nopetugas }
\end{aligned}
$$

\begin{tabular}{|l|l|l|l|}
\hline Nama File & $\begin{array}{l}\text { Tipe } \\
\text { Data }\end{array}$ & Ukuran & Ket \\
\hline Nopetugas & Int & 11 & Primary \\
\hline Petugas & Var & 50 & \\
\hline Username & Var & 50 & \\
\hline Password & Var & 32 & \\
\hline foto_petugas & Var & 100 & \\
\hline Level & Int & 11 & \\
\hline Status & Int & 11 & \\
\hline
\end{tabular}

4. Tabel Mahasiswa

Nama

Type File

Primary Key
: Siswa

: Master

: nomember

\begin{tabular}{|l|l|l|l|}
\hline Nama File & $\begin{array}{l}\text { Tipe } \\
\text { Data }\end{array}$ & Ukuran & Ket \\
\hline Nomember & Bigint & 100 & $\begin{array}{l}\text { Primary } \\
\text { Key }\end{array}$ \\
\hline foto_siswa & Var & 100 & \\
\hline nama_siswa & Var & 100 & \\
\hline Password & Var & 100 & \\
\hline Jenkel & Var & 20 & \\
\hline Kelas & Var & 20 & \\
\hline Notelp & Var & 20 & \\
\hline Agama & Var & 20 & \\
\hline
\end{tabular}

DOI: $10.52362 /$ jisicom.v5i1.384

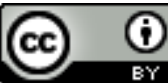

Ciptaan disebarluaskan di bawahLisensi Creative Commons Atribusi 4.0 Internasional. 
e-ISSN : 2597-3673 (Online) , p-ISSN : 2579-5201 (Printed)

Vol.5 No.1, Juni 2021

Journal of Information System, Informatics and Computing

Website/URL: http://journal.stmikjayakarta.ac.id/index.php/iisicom

Email: jisicom@stmikjayakarta.ac.id , jisicom2017@gmail.com

5. Tabel Pinjam

\begin{tabular}{|l|l|l|l|}
\hline Email & Var & 50 & \\
\hline Alamat & Text & & \\
\hline
\end{tabular}

Nama

Type File

: tbl_pinjam

Primary Key

: Master

Foregen Key

: kdbuku

: nomember

\begin{tabular}{|c|c|c|c|}
\hline Nama File & $\begin{array}{l}\text { Tipe } \\
\text { Data }\end{array}$ & $\begin{array}{l}\text { Ukura } \\
\text { n }\end{array}$ & Ket \\
\hline Kdbuku & Var & 11 & $\begin{array}{l}\text { Primary } \\
\text { Key }\end{array}$ \\
\hline Nomember & Bigint & 100 & $\begin{array}{l}\text { Foregen } \\
\text { Key }\end{array}$ \\
\hline tgl_pinjam & $\begin{array}{l}\text { Datean } \\
\text { dtime }\end{array}$ & & \\
\hline tgl_kembali & $\begin{array}{l}\text { Datean } \\
\text { dtime }\end{array}$ & & \\
\hline tgl_terima & $\begin{array}{l}\text { Datean } \\
\text { dtime }\end{array}$ & & \\
\hline
\end{tabular}

6. Tabel Kembali

Nama

: tbl_kembali

Type File

: Master

Primary Key

: kdbuku

ForegenKey

: nomember

\begin{tabular}{|c|c|c|c|}
\hline Nama File & $\begin{array}{l}\text { Tipe } \\
\text { Data }\end{array}$ & $\begin{array}{l}\text { Ukura } \\
\text { n }\end{array}$ & Ket \\
\hline Kdbuku & Var & 11 & $\begin{array}{l}\text { Primary } \\
\text { Key }\end{array}$ \\
\hline Nomember & Bigint & 100 & $\begin{array}{l}\text { Foregen } \\
\text { Key }\end{array}$ \\
\hline tgl_pinjam & $\begin{array}{l}\text { Datean } \\
\text { dtime }\end{array}$ & & \\
\hline tgl_kembali & $\begin{array}{l}\text { Datean } \\
\text { dtime }\end{array}$ & & \\
\hline tgl_terima & $\begin{array}{l}\text { Datean } \\
\text { dtime }\end{array}$ & & \\
\hline Denda & Int & 11 & \\
\hline
\end{tabular}

DOI: $10.52362 /$ jisicom.v5i1.384

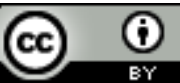

Ciptaan disebarluaskan di bawahLisensi Creative Commons Atribusi 4.0 Internasional. 
Journal of Information System, Informatics and Computing

Website/URL: http://journal.stmikjayakarta.ac.id/index.php/jisicom

Email: jisicom@stmikjayakarta.ac.id, jisicom2017@gmail.com

\subsection{Rancangan Antar Muka Sistem Usulan}

Perancangan antar muka menggambarkan rancangan tampilan yang ada dalam sistem yang diusulkan. Berikut ini perancangan tampilan menu utama:

Login

Halaman Login digunakan untuk masuk ke dalam halaman menu untuk mengakses sistem. Berikut gambar dari halaman login:

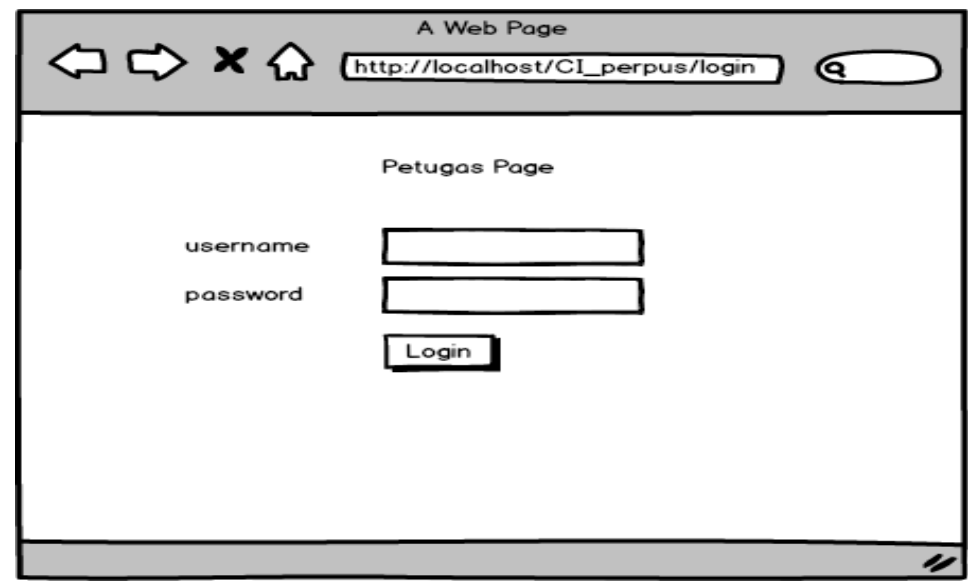

Cari Buku

Berikut ini perancangan form cari buku pada aplikasi yang dibuat:

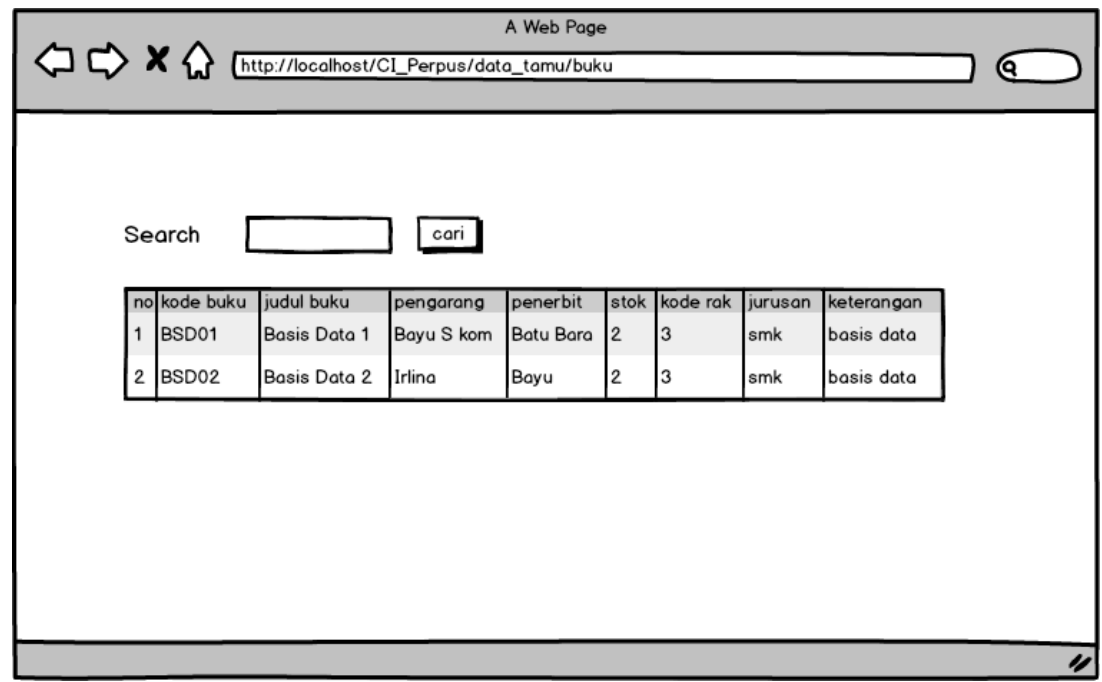

Data Transaksi Pinjam

Berikut ini perancangan form view data transaksi pinjam buku pada aplikasi yang dibuat:

DOI: $10.52362 /$ jisicom.v5i1.384

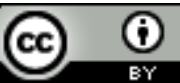

Ciptaan disebarluaskan di bawahLisensi Creative Commons Atribusi 4.0 Internasional. 
e-ISSN : 2597-3673 (Online) , p-ISSN : 2579-5201 (Printed)

Vol.5 No.1, Juni 2021

Journal of Information System, Informatics and Computing

Website/URL: http://journal.stmikjayakarta.ac.id/index.php/jisicom

Email: jisicom@stmikjayakarta.ac.id, jisicom2017@gmail.com

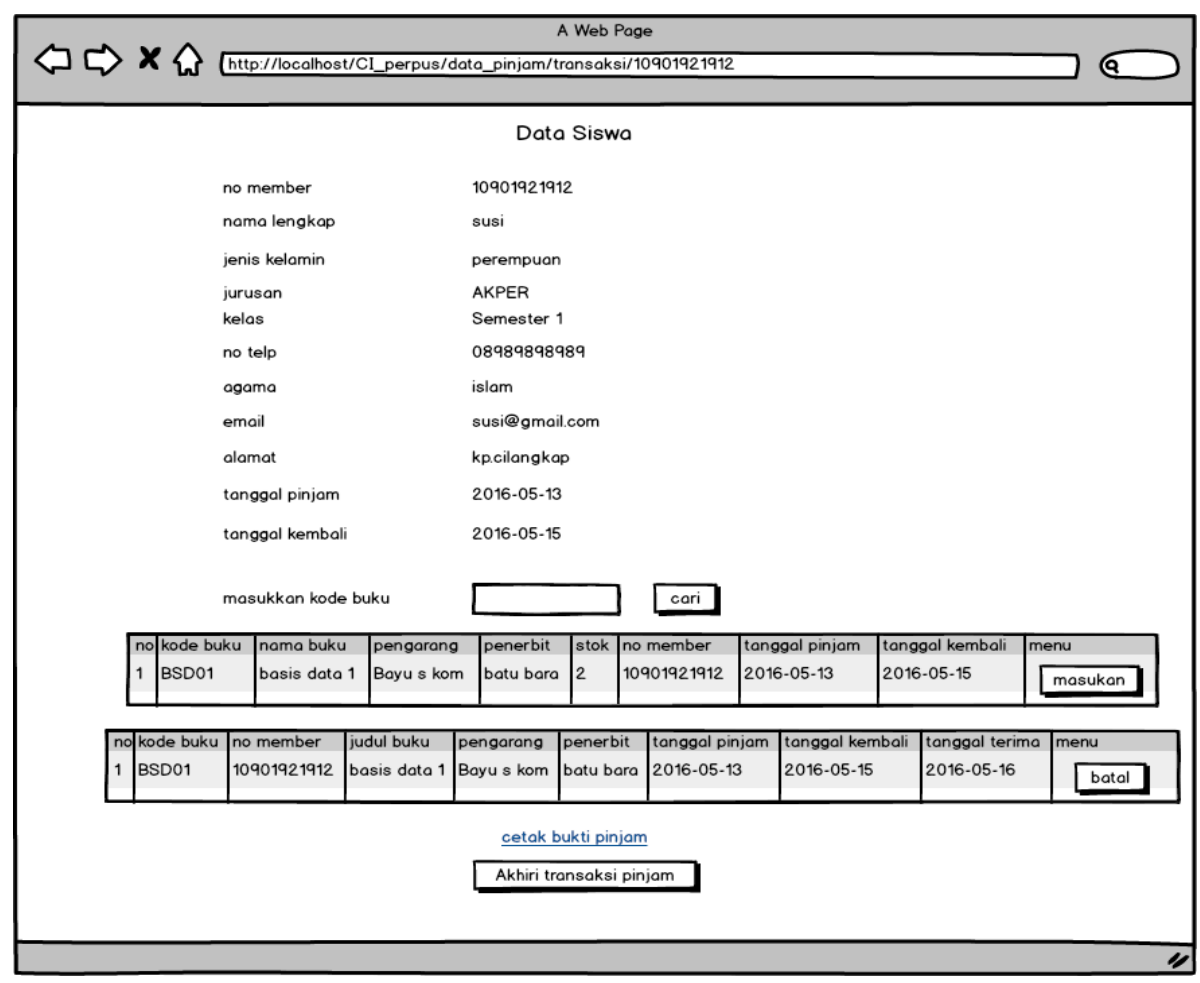

Data Transaksi Kembali

Berikut ini perancangan form view data kembali pinjaman buku pada aplikasi yang dibuat:

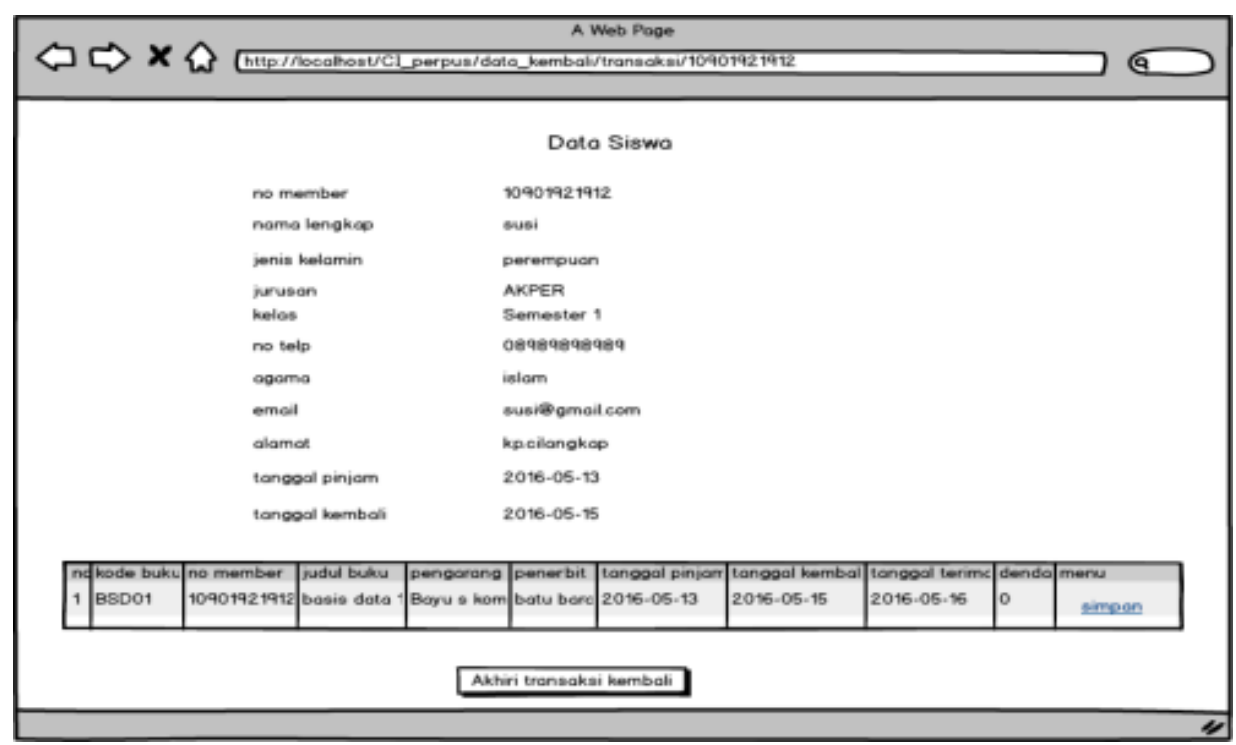

Layout Halaman Login Admin \& Petugas

DOI: $10.52362 /$ jisicom.v5i1.384

(c) (i)

Ciptaan disebarluaskan di bawahLisensi Creative Commons Atribusi 4.0 Internasional. 
e-ISSN : 2597-3673 (Online) , p-ISSN : 2579-5201 (Printed)

Vol.5 No.1, Juni 2021

Journal of Information System, Informatics and Computing

Website/URL: http://journal.stmikjayakarta.ac.id/index.php/jisicom

Email: jisicom@stmikjayakarta.ac.id, jisicom2017@gmail.com

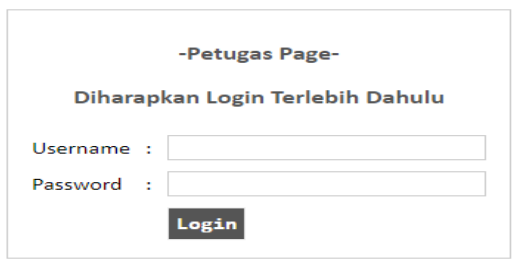

4.6. Implementasi Antar Muka Sistem Usulan

Halaman Login Anggota

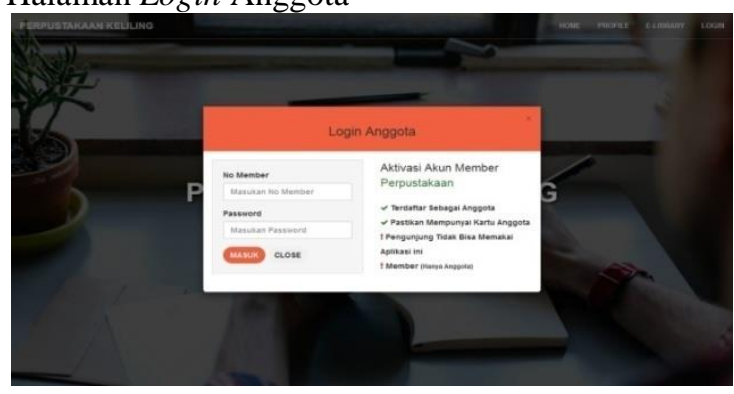

Halaman Dashboard

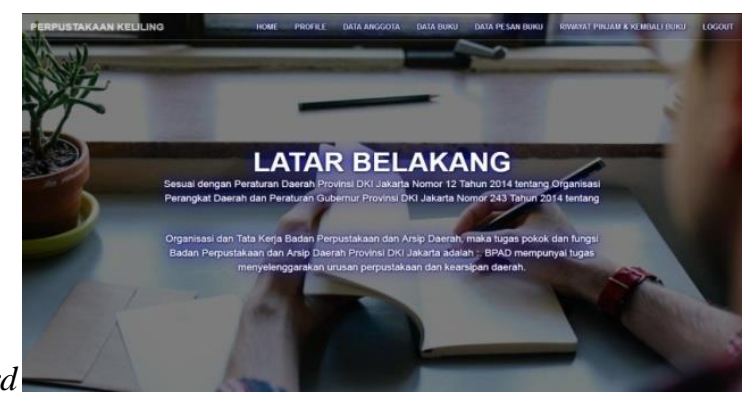

Layout Halaman Admin

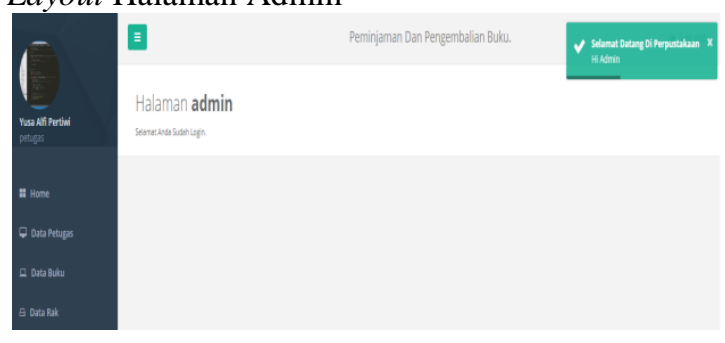

Layout Halaman Petugas

DOI: $10.52362 /$ jisicom.v5i1.384

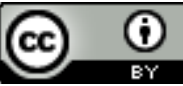

Ciptaan disebarluaskan di bawahLisensi Creative Commons Atribusi 4.0 Internasional. 
e-ISSN : 2597-3673 (Online) , p-ISSN : 2579-5201 (Printed)

Vol.5 No.1, Juni 2021

Journal of Information System, Informatics and Computing

Website/URL: http://journal.stmikjayakarta.ac.id/index.php/iisicom

Email: jisicom@stmikjayakarta.ac.id, jisicom2017@gmail.com

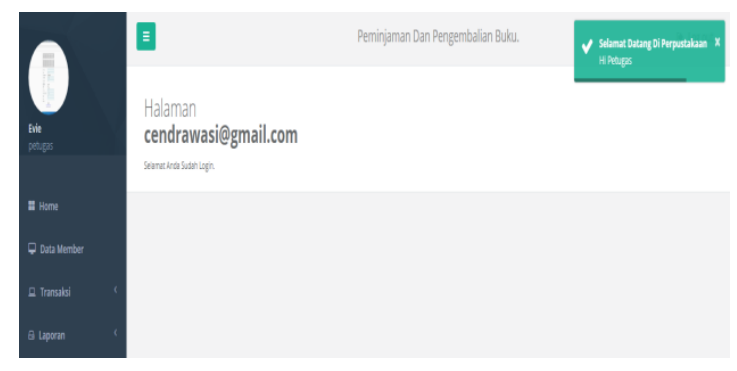

Layout Halaman Anggota

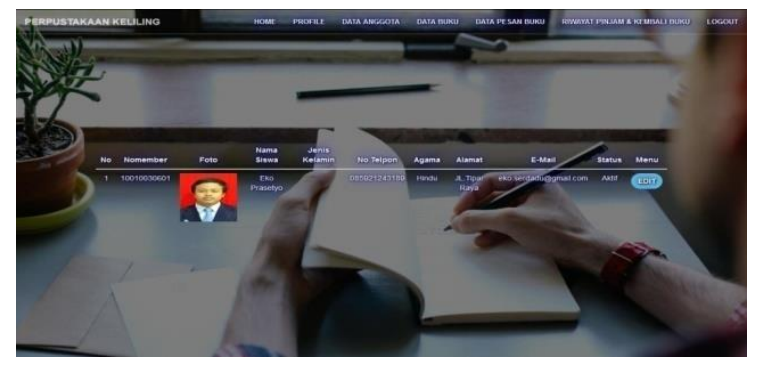

6. Layout Halaman Buku

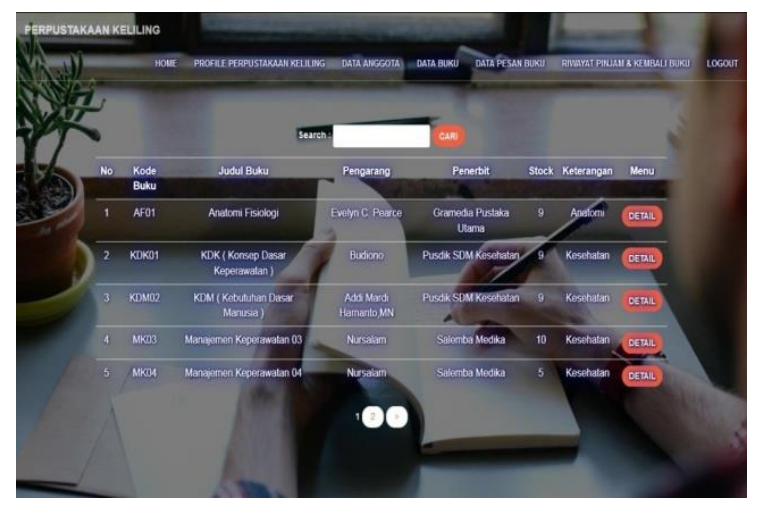

Layout Halaman Pesan Buku

DOI: $10.52362 /$ jisicom.v5i1.384

(c) (7)

Ciptaan disebarluaskan di bawahLisensi Creative Commons Atribusi 4.0 Internasional. 


\section{Journal of Information System, Informatics and Computing}

Website/URL: http://journal.stmikjayakarta.ac.id/index.php/iisicom

Email: jisicom@stmikjayakarta.ac.id , jisicom2017@gmail.com

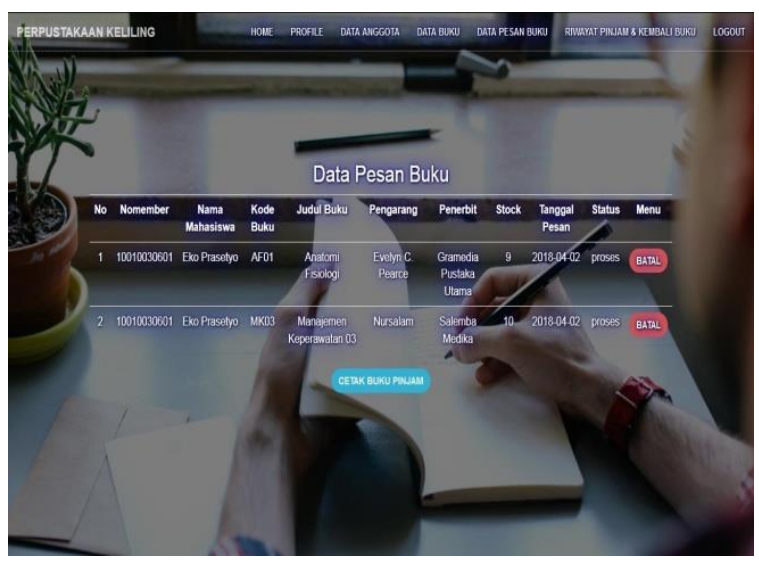

Layout Halaman Riwayat Pinjam Buku

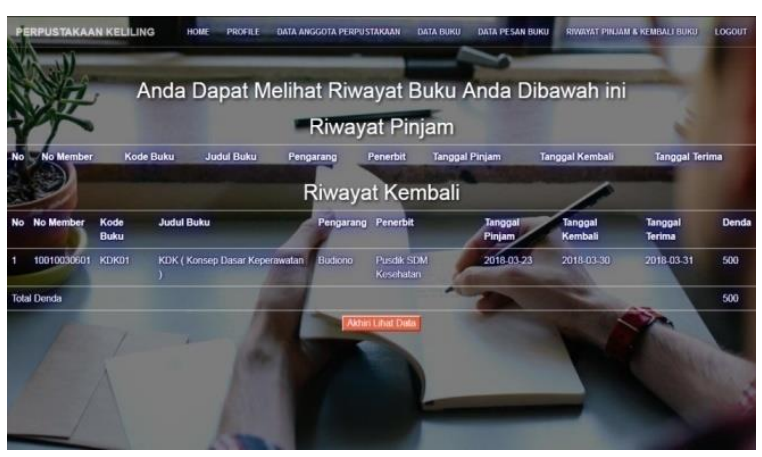

Layout Halaman Kategori

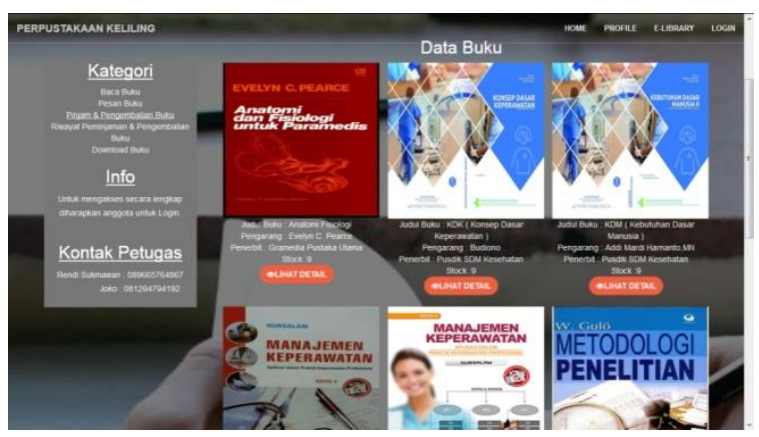

\subsection{Spesifikasi sistem komputer}

Dalam perancangan aplikasi ini dibutuhkan beberapa kebutuhan

infrastruktur dalam proses perancangan aplikasi ini. Dan juga Penulis merekomendasikan minimum untuk kebutuhan infrastruktur pendukung aplikasi ini.

\section{Sistem Operasi \\ Windows 7 ultimate / windows 10}

DOI: $10.52362 /$ jisicom.v5i1.384

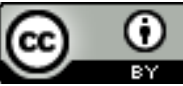

Ciptaan disebarluaskan di bawahLisensi Creative Commons Atribusi 4.0 Internasional. 
Journal of Information System, Informatics and Computing

Website/URL: http://journal.stmikjayakarta.ac.id/index.php/iisicom

Email: jisicom@stmikjayakarta.ac.id, jisicom2017@gmail.com

\section{Kebutuhan Hardware}

1) Processor Intel Core i5,

2) $R A M 4 \mathrm{~GB}$,

3) Disk 1024 GB,

4) Mouse

5) Keyboard

6) Printer

\section{Kebutuhan Software}
1) Program
2) Database
3) Web server
4) Web browser
: MySql
: XAMPP version 1.7 .7
5) Aplikasi editor
Mozilla Firefox / Google Chrome
6) Aplikasi design
: Notepad ++
: Star UML

\subsection{Pengujian Sistem}

Pengujian merupakan bagian yang penting dalam siklus pembangunan perangkat lunak. Pengujian dilakukan untuk menjamin kualitas dan juga mengetahui kelemahan dari perangkat lunak. Tujuan dari pengujian ini adalah untuk menjamin bahwa perangkat lunak yang dibangun memiliki kualitas yang baik, yaitu sesuai dengan analisis, perancangan dan pengkodean dari perangkat lunak itu sendiri, serta mampu memenuhi kebutuhan pengguna.

Adapun tahapan-tahapannya meliputi :

\section{Rencana Pengujian}

Pengujian perangkat lunak ini menggunakan metode

berdasarkan konsep pengujian black box. Pengujian black box mengidentifikasi kesalahan yang berhubungan dengan kesalahan fungsionalitas perangkat lunak yang tampak dalam kesalahan output, dan tidak terfokus pada source code sistem. Pengujian black box ini memungkinkan untuk melakukan pengujian semua functional requirement dengan memasukkan input dan melihat hasil yang diberikan oleh sistem. Metode pengujian ini dijalankan setelah sistem selesai dibangun. Rencana pengujian selanjutnya dapat di lihat pada tabel Rencana Pengujian Program berikut :

\begin{tabular}{|l|l|c|l|}
\hline Kelas Uji & \multicolumn{1}{|c|}{ Butir Uji } & $\begin{array}{c}\text { Tingkat } \\
\text { Pengujia } \\
\mathrm{n}\end{array}$ & $\begin{array}{l}\text { Jenis } \\
\text { Peng } \\
\text { ujian }\end{array}$ \\
\hline $\begin{array}{l}\text { Menu } \\
\text { Beranda }\end{array}$ & $\begin{array}{l}\text { Tampilan menu } \\
\text { yang disimpan } \\
\text { kedalam sistem }\end{array}$ & Sistem & $\begin{array}{l}\text { Black } \\
\text { Box }\end{array}$ \\
\hline $\begin{array}{l}\text { Menu } \\
\text { Keferensi } \\
\text { Klasifikasi }\end{array}$ & $\begin{array}{l}\text { Mencari dan } \\
\text { Melihat list } \\
\text { Klasifikasi } \\
\text { buku-buku }\end{array}$ & Sistem & $\begin{array}{l}\text { Black } \\
\text { Box }\end{array}$ \\
\hline $\begin{array}{l}\text { Menu } \\
\text { Transaksi }\end{array}$ & $\begin{array}{l}\text { Mengolah buku } \\
\text { masuk dan buku } \\
\text { Keluar }\end{array}$ & Sistem & $\begin{array}{l}\text { Black } \\
\text { Box }\end{array}$ \\
\hline
\end{tabular}

DOI: $10.52362 /$ jisicom.v5i1.384

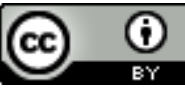

Ciptaan disebarluaskan di bawahLisensi Creative Commons Atribusi 4.0 Internasional. 
Journal of Information System, Informatics and Computing

Website/URL: http://journal.stmikjayakarta.ac.id/index.php/jisicom

Email: jisicom@stmikjayakarta.ac.id, jisicom2017@gmail.com

\begin{tabular}{|l|l|l|l|}
\hline $\begin{array}{l}\text { Menu } \\
\text { Buku } \\
\text { Agenda }\end{array}$ & $\begin{array}{l}\text { Mengolah buku } \\
\text { masuk dan buku } \\
\text { Keluar }\end{array}$ & Sistem & $\begin{array}{l}\text { Black } \\
\text { Box }\end{array}$ \\
\hline $\begin{array}{l}\text { Menu } \\
\text { Pengaturan }\end{array}$ & $\begin{array}{l}\text { Mengolah } \\
\text { Instansi } \\
\text { pengguna dan } \\
\text { Manajemen } \\
\text { Admin }\end{array}$ & Sistem & $\begin{array}{l}\text { Black } \\
\text { Box }\end{array}$ \\
\hline
\end{tabular}

\section{Kasus dan Hasil Pengujian}

Kasus dan hasil penghujian dibuat untuk mengetahui apakah Dalam Pengelolaan Data Buku-buku perpustakaan keliling Berbasis Web Pada Pada Suku Dinas Perpustakaan dan Kearsipan Kota Administrasi Jakarta Utara dapat berjalan dengan baik atau tidak.

Berdasarkan rencana pengujian yang telah disusun, maka dapat dilakukan pengujian sebagai berikut:

\section{Kelas Uji Login}

Berikut ini adalah tabel pengujian login Admin untuk pengecekan yang telah terdaftar :

\begin{tabular}{|c|c|c|c|}
\hline \multicolumn{4}{|c|}{ Kasus dan Hasil Uji } \\
\hline $\begin{array}{l}\text { Data } \\
\text { Masuk }\end{array}$ & $\begin{array}{l}\text { Yang } \\
\text { diharapka } \\
\text { n }\end{array}$ & $\begin{array}{l}\text { Pengam } \\
\text { atan }\end{array}$ & $\begin{array}{l}\text { Kesim } \\
\text { pulan }\end{array}$ \\
\hline $\begin{array}{l}\text { Status: } \\
\text { Admin } \\
\text { User } \\
\text { admin } \\
\text { Passwor } \\
d: \text { admin }\end{array}$ & $\begin{array}{l}\text { Dapat } \\
\text { Login dan } \\
\text { masuk ke } \\
\text { halaman } \\
\text { utama } \\
\text { admin }\end{array}$ & $\begin{array}{l}\text { Menampi } \\
\text { lkan form } \\
\text { menu } \\
\text { utama } \\
\text { admin } \\
\text { sesuai } \\
\text { yang } \\
\text { diharapk } \\
\text { an }\end{array}$ & $\begin{array}{l}{[\mathrm{X}]} \\
\text { Diteri } \\
\text { ma } \\
{[\quad]} \\
\text { Ditolak }\end{array}$ \\
\hline
\end{tabular}

DOI: $10.52362 /$ jisicom.v5i1.384

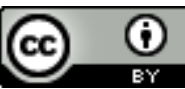

Ciptaan disebarluaskan di bawahLisensi Creative Commons Atribusi 4.0 Internasional. 
e-ISSN : 2597-3673 (Online) , p-ISSN : 2579-5201 (Printed)

Vol.5 No.1, Juni 2021

Journal of Information System, Informatics and Computing

Website/URL: http://journal.stmikjayakarta.ac.id/index.php/jisicom

Email: jisicom@stmikjayakarta.ac.id , jisicom2017@gmail.com

\begin{tabular}{|c|c|c|c|}
\hline $\begin{array}{l}\text { Status: } \\
\text { Regular } \\
\text { User } \\
\text { Inputan } \\
\text { usernam } \\
\text { e dengan } \\
\text { user } \\
\text { regular } \\
\text { user dan } \\
\text { passwor } \\
\text { d diisi } \\
\text { sesuai } \\
\text { dengan } \\
\text { user } \\
\text { name } \\
\text { yang } \\
\text { dipilih }\end{array}$ & $\begin{array}{l}\text { Dapat } \\
\text { masuk ke } \\
\text { halaman } \\
\text { utama } \\
\text { Regular } \\
\text { User }\end{array}$ & $\begin{array}{l}\text { Menampi } \\
\text { lkan form } \\
\text { menu } \\
\text { utama } \\
\text { admin } \\
\text { sesuai } \\
\text { yang } \\
\text { diharapk } \\
\text { an }\end{array}$ & $\begin{array}{l}{[\mathbf{X}]} \\
\text { Diteri } \\
\text { ma } \\
{[\quad]} \\
\text { Ditolak }\end{array}$ \\
\hline $\begin{array}{l}\text { User } \\
\text { name: } \\
\text { bebas } \\
\text { Passwor } \\
d: \text { bebas }\end{array}$ & $\begin{array}{l}\text { Tidak } \\
\text { dapat login } \\
\text { dan } \\
\text { menampilk } \\
\text { an pesan } \\
\text { kesalahan }\end{array}$ & $\begin{array}{l}\text { User } \\
\text { tidak } \\
\text { dapat } \\
\text { login jika } \\
\text { salah } \\
\text { Usernam } \\
e \quad \text { dan } \\
\text { atau } \\
\text { Passwor } \\
d\end{array}$ & $\begin{array}{l}{[\mathbf{X}]} \\
\text { Diteri } \\
\text { ma } \\
{[\quad]} \\
\text { Ditolak }\end{array}$ \\
\hline
\end{tabular}

\section{Kelas Uji Menu Arsip}

Berikut ini adalah tabel pengujian Arsip untuk pengecekan yang telah terdaftar :

\begin{tabular}{|c|c|c|c|}
\hline \multicolumn{4}{|c|}{ Kasus dan Hasil uji } \\
\hline $\begin{array}{l}\text { Data } \\
\text { Masuk }\end{array}$ & $\begin{array}{l}\text { Yang Di } \\
\text { Harapkan }\end{array}$ & $\begin{array}{l}\text { Penga } \\
\text { matan }\end{array}$ & $\begin{array}{l}\text { Kesimpu } \\
\text { lan }\end{array}$ \\
\hline $\begin{array}{l}\text { Setiap } \\
\text { user } \\
\text { dapat } \\
\text { menam } \\
\text { pilkan } \\
\text { klasifik } \\
\text { asi } \\
\text { buku }\end{array}$ & $\begin{array}{l}\text { Sistem } \\
\text { akan } \\
\text { menampilk } \\
\text { an form } \\
\text { klasifikasi } \\
\text { buku. Dan } \\
\text { Dapat } \\
\text { mencari } \\
\text { dokumen } \\
\text { buku yang } \\
\text { diinginkan } \\
\text { di simpan }\end{array}$ & $\begin{array}{l}\text { Sesuai } \\
\text { yang di } \\
\text { harapka } \\
n\end{array}$ & $\begin{array}{l}{[\mathrm{X}]} \\
\text { Diterima } \\
{[} \\
\text { Ditolak }\end{array}$ \\
\hline
\end{tabular}

DOI: $10.52362 /$ jisicom.v5i1.384

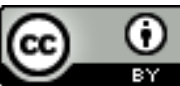

Ciptaan disebarluaskan di bawahLisensi Creative Commons Atribusi 4.0 Internasional. 
Journal of Information System, Informatics and Computing

Website/URL: http://journal.stmikjayakarta.ac.id/index.php/iisicom

Email: jisicom@stmikjayakarta.ac.id , jisicom2017@gmail.com

\begin{tabular}{|c|c|c|c|}
\hline & $\begin{array}{l}\text { kedalam } \\
\text { sistem. }\end{array}$ & & \\
\hline $\begin{array}{l}\text { Setiap } \\
\text { user } \\
\text { dapat } \\
\text { melaku } \\
\text { kan } \\
\text { transak } \\
\text { si buku } \\
\text { masuk } \\
\text { dan } \\
\text { buku } \\
\text { keluar }\end{array}$ & $\begin{array}{l}\text { Sistem } \\
\text { akan } \\
\text { menampilk } \\
\text { an menu } \\
\text { transaksi } \\
\text { buku } \\
\text { masuk dan } \\
\text { buku } \\
\text { keluar. } \\
\text { Dimana } \\
\text { dapat } \\
\text { melakukan } \\
\text { edit buku, } \\
\text { delete } \\
\text { buku, } \\
\text { disposisi } \\
\text { buku dan } \\
\text { cetak buku }\end{array}$ & $\begin{array}{l}\text { Sesuai } \\
\text { yang di } \\
\text { harapka } \\
\text { n }\end{array}$ & $\begin{array}{l}{[\mathrm{X}]} \\
\text { Diterima } \\
{[} \\
\text { Ditolak }\end{array}$ \\
\hline $\begin{array}{l}\text { Setiap } \\
\text { user } \\
\text { dapat } \\
\text { melaku } \\
\text { kan } \\
\text { pada } \\
\text { buku } \\
\text { agenda, } \\
\text { buku } \\
\text { masuk } \\
\text { dan } \\
\text { buku } \\
\text { keluar }\end{array}$ & $\begin{array}{l}\text { Sistem } \\
\text { akan } \\
\text { menampilk } \\
\text { an menu } \\
\text { agenda } \\
\text { buku } \\
\text { masuk dan } \\
\text { buku } \\
\text { keluar. } \\
\text { Dimana } \\
\text { dapat } \\
\text { melakukan } \\
\text { cetak } \\
\text { buku }\end{array}$ & $\begin{array}{l}\text { Sesuai } \\
\text { yang di } \\
\text { harapka } \\
\text { n }\end{array}$ & $\begin{array}{l}{[\mathrm{X}]} \\
\text { Diterima } \\
{[} \\
\text { Ditolak }\end{array}$ \\
\hline
\end{tabular}

DOI: $10.52362 /$ jisicom.v5i1.384 
Journal of Information System, Informatics and Computing

Website/URL: http://journal.stmikjayakarta.ac.id/index.php/jisicom

Email: jisicom@stmikjayakarta.ac.id , jisicom2017@gmail.com

\begin{tabular}{|c|c|c|c|}
\hline $\begin{array}{l}\text { Setiap } \\
\text { user } \\
\text { dapat } \\
\text { melaku } \\
\text { kan } \\
\text { pada } \\
\text { menu } \\
\text { pengatu } \\
\text { ran } \\
\text { pada } \\
\text { instansi } \\
\text { penggu } \\
\text { na dan } \\
\text { manaje } \\
\text { men } \\
\text { penggu } \\
\text { na }\end{array}$ & $\begin{array}{l}\text { Pada } \\
\text { Instansi } \\
\text { Pengguna } \\
\text { yang di } \\
\text { upload } \\
\text { oleh user } \\
\text { dapat di } \\
\text { edit oleh } \\
\text { user yang } \\
\text { menguploa } \\
\text { d, dan juga } \\
\text { oleh admin }\end{array}$ & $\begin{array}{l}\text { Sesuai } \\
\text { yang di } \\
\text { harapka } \\
\text { n }\end{array}$ & $\begin{array}{l}{[\mathbf{X}]} \\
\text { Diterima } \\
{[} \\
\text { Ditolak }\end{array}$ \\
\hline $\begin{array}{l}\text { Setiap } \\
\text { User } \\
\text { dapat } \\
\text { Searchi } \\
\text { ng } \\
\text { Dokum } \\
\text { en } \\
\text { buku }\end{array}$ & $\begin{array}{l}\text { Sistem } \\
\text { akan } \\
\text { menampilk } \\
\text { an file/ } \\
\text { dokumen } \\
\text { yang di } \\
\text { searching }\end{array}$ & $\begin{array}{l}\text { Apabila } \\
\text { file } \\
\text { atau } \\
\text { dokum } \\
\text { en } \\
\text { tersebut } \\
\text { ada di } \\
\text { dalam } \\
\text { sistem } \\
\text { tersebut }\end{array}$ & $\begin{array}{l}{[\mathbf{X}]} \\
\text { Diterima } \\
{[} \\
\text { Ditolak }\end{array}$ \\
\hline
\end{tabular}

5. Kelas Uji Login

Berikut ini adalah tabel pengujian login Admin untuk pengecekan yang telah terdaftar :

\begin{tabular}{|c|c|c|c|}
\hline \multicolumn{4}{|c|}{ Kasus dan Hasil Uji } \\
\hline $\begin{array}{l}\text { Data } \\
\text { Masuk }\end{array}$ & $\begin{array}{l}\text { Yang Di } \\
\text { Harapkan }\end{array}$ & $\begin{array}{l}\text { Pengamata } \\
\text { n }\end{array}$ & $\begin{array}{l}\text { Kesimpu } \\
\text { lan }\end{array}$ \\
\hline $\begin{array}{l}\text { Setiap } \\
\text { User } \\
\text { dapat } \\
\text { melihat } \\
\text { data } \\
\text { pribadi } \\
\text { nya }\end{array}$ & $\begin{array}{l}\text { Sistem } \\
\text { akan } \\
\text { menampilk } \\
\text { an data } \\
\text { profile } \\
\text { pribadinya }\end{array}$ & $\begin{array}{l}\text { Sesuai yang } \\
\text { di harapkan }\end{array}$ & $\begin{array}{l}{[\mathrm{X}]} \\
\text { Diterima } \\
{[} \\
\text { Ditolak }\end{array}$ \\
\hline $\begin{array}{l}\text { Setiap } \\
\text { User } \\
\text { dapat } \\
\text { mengu } \\
\text { bah } \\
\text { data }\end{array}$ & $\begin{array}{l}\text { Sistem } \\
\text { akan } \\
\text { mengubah } \\
\text { data profile } \\
\text { pribadinya }\end{array}$ & $\begin{array}{l}\text { Sesuai yang } \\
\text { di harapkan }\end{array}$ & $\begin{array}{l}{[\mathbf{X}]} \\
\text { Diterima } \\
{[} \\
\text { Ditolak }\end{array}$ \\
\hline
\end{tabular}

DOI: $10.52362 /$ jisicom.v5i1.384

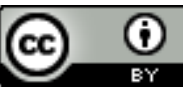

Ciptaan disebarluaskan di bawahLisensi Creative Commons Atribusi 4.0 Internasional. 
e-ISSN : 2597-3673 (Online) , p-ISSN : 2579-5201 (Printed)

Vol.5 No.1, Juni 2021

Journal of Information System, Informatics and Computing

Website/URL: http://journal.stmikjayakarta.ac.id/index.php/jisicom

Email: jisicom@stmikjayakarta.ac.id , jisicom2017@gmail.com

\begin{tabular}{|c|c|c|c|}
\hline $\begin{array}{l}\text { pribadi } \\
\text { nya }\end{array}$ & & & \\
\hline $\begin{array}{l}\text { Admini } \\
\text { strator } \\
\text { dapat } \\
\text { menam } \\
\text { bahkan } \\
\text { user } \\
\text { pada } \\
\text { sistem }\end{array}$ & $\begin{array}{l}\text { Sistem } \\
\text { akan } \\
\text { menyimpa } \\
\text { n data-data } \\
\text { user }\end{array}$ & $\begin{array}{l}\text { Sesuai yang } \\
\text { di harapkan }\end{array}$ & $\begin{array}{l}{[\mathrm{X}]} \\
\text { Diterima } \\
{[} \\
\text { Ditolak }\end{array}$ \\
\hline $\begin{array}{l}\text { Admini } \\
\text { strator } \\
\text { dapat } \\
\text { melihat } \\
\text { data } \\
\text { semua } \\
\text { user }\end{array}$ & $\begin{array}{l}\text { Sistem } \\
\text { akan } \\
\text { menampilk } \\
\text { an data } \\
\text { semua } \text { user }\end{array}$ & $\begin{array}{l}\text { Sesuai yang } \\
\text { di harapkan }\end{array}$ & $\begin{array}{l}{[\mathrm{X}]} \\
\text { Diterima } \\
{[} \\
\text { Ditolak }\end{array}$ \\
\hline $\begin{array}{l}\text { Admini } \\
\text { strator } \\
\text { dapat } \\
\text { mengu } \\
\text { bah } \\
\text { data } \\
\text { user } \\
\text { profile }\end{array}$ & $\begin{array}{l}\text { Sistem } \\
\text { akan } \\
\text { mengubah } \\
\text { data user } \\
\text { profile }\end{array}$ & $\begin{array}{l}\text { Sesuai yang } \\
\text { di harapkan }\end{array}$ & $\begin{array}{l}{[\mathbf{X}]} \\
\text { Diterima } \\
{[} \\
\text { Ditolak }\end{array}$ \\
\hline $\begin{array}{l}\text { Admini } \\
\text { strator } \\
\text { dapat } \\
\text { mengga } \\
\text { nti tipe } \\
\text { user }\end{array}$ & $\begin{array}{l}\text { Sistem } \\
\text { akan } \\
\text { mengganti } \\
\text { tipe } \text { user }\end{array}$ & $\begin{array}{l}\text { Sesuai yang } \\
\text { di harapkan }\end{array}$ & $\begin{array}{l}{[\mathrm{X}]} \\
\text { Diterima } \\
{[} \\
\text { Ditolak }\end{array}$ \\
\hline
\end{tabular}

\section{Kelas Uji Keseluruhan menu}

Berikut ini adalah tabel pengujian keseluruhan menu untuk pengecekan yang telah terdaftar :

\begin{tabular}{|l|l|l|l|}
\hline \multicolumn{4}{|c|}{ Kasus dan Hasil Uji } \\
\hline $\begin{array}{l}\text { Data } \\
\text { Masuk }\end{array}$ & $\begin{array}{l}\text { Yang Di } \\
\text { Harapkan }\end{array}$ & Pengamatan & $\begin{array}{l}\text { Kesim } \\
\text { pulan }\end{array}$ \\
\hline $\begin{array}{l}\text { Admini } \\
\text { strator } \\
\text { dapat } \\
\text { menam } \\
\text { bah } \\
\text { buku }\end{array}$ & $\begin{array}{l}\text { Sistem akan } \\
\text { menampilka } \\
\text { tambah form }\end{array}$ & $\begin{array}{l}\text { Sesuai yang } \\
\text { di harapkan }\end{array}$ & $\begin{array}{l}{[\mathbf{X}]} \\
\text { Diteri } \\
\text { ma }\end{array}$ \\
\hline
\end{tabular}

DOI: $10.52362 /$ jisicom.v5i1.384

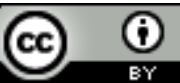

Ciptaan disebarluaskan di bawahLisensi Creative Commons Atribusi 4.0 Internasional. 
Journal of Information System, Informatics and Computing

Website/URL: http://journal.stmikjayakarta.ac.id/index.php/iisicom

Email: jisicom@stmikjayakarta.ac.id, jisicom2017@gmail.com

\begin{tabular}{|c|c|c|c|}
\hline buku & Buku & & Ditolak \\
\hline $\begin{array}{l}\text { Admini } \\
\text { strator } \\
\text { dapat } \\
\text { mengha } \\
\text { pus } \\
\text { buku } \\
\text { yang } \\
\text { telah } \\
\text { ada }\end{array}$ & $\begin{array}{l}\text { Akan } \\
\text { menghapus } \\
\text { data buku }\end{array}$ & $\begin{array}{l}\text { Sesuai yang } \\
\text { di harapkan }\end{array}$ & $\begin{array}{l}{[\mathrm{X}]} \\
\text { Diteri } \\
\text { ma } \\
{[\quad]} \\
\text { Ditolak }\end{array}$ \\
\hline $\begin{array}{l}\text { Admini } \\
\text { strator } \\
\text { dapat } \\
\text { mengu } \\
\text { bah } \\
\text { arsip }\end{array}$ & $\begin{array}{l}\text { Sistem akan } \\
\text { mengubah } \\
\text { data buku }\end{array}$ & $\begin{array}{l}\text { Sesuai yang } \\
\text { di harapkan }\end{array}$ & $\begin{array}{l}{[X]} \\
\text { Diteri } \\
\text { ma } \\
{[\quad]} \\
\text { Ditolak }\end{array}$ \\
\hline $\begin{array}{l}\text { Admini } \\
\text { strator } \\
\text { dapat } \\
\text { mencet } \\
\text { ak } \\
\text { buku- } \\
\text { buku }\end{array}$ & $\begin{array}{l}\text { Sistem akan } \\
\text { mencetak } \\
\text { data buku } \\
\text { yang } \\
\text { diinginkan }\end{array}$ & $\begin{array}{l}\text { Sesuai yang } \\
\text { di harapkan }\end{array}$ & $\begin{array}{l}{[\mathrm{X}]} \\
\text { Diteri } \\
\text { ma } \\
{[} \\
\text { Ditolak }\end{array}$ \\
\hline
\end{tabular}

\section{PEMBAHASAN DAN HASIL}

\subsection{Kesimpulan}

Setelah Penulis menyelesaikan penulisan Skripsi ini, maka dapat diambil beberapa kesimpulan, diantaranya:

1. Sistem informasi Perpustakaan Keliling yang berjalan pada Suku Dinas Perpustakaan dan Kearsipan Kota Administrasi Jakarta Utara. masih dilakukan secara manual. Banyak kendala yang dihadapi selama proses peminjaman dan pengembalian buku yang berjalan saat ini yang memperlambat jalannya kegiatan peminjaman dan pengembalian buku, sehingga tidak berjalan secara efektif dan efisien.

2. Penggunaan sistem perpustakaan keliling berbasis web sangatlah

penting dalam segala kegiatan khususnya dalam kegiatan piminjaman dan pengembalian buku karena dapat menghemat waktu dan tenaga. Hasilnya akan lebih efektif dan efisien dibandingkan secara manual. Sistem informasi perpustakaan keliling yang sudah berbasis web dapat menghasilkan laporan yang lebih akurat dan tepat waktu sehingga menghasilkan informasi yang bermutu dan dapat digunakan dalam pengambilan keputusan.

3. Bentuk dokumen harus diubah, karena dalam penyimpanan yang tidak efisien tidak aman dan masih menggunakan cara menumpukan data atau arsip yang dapat mengakibatkan kerusakan atau hilang dan pencarian data yang sulit.

\subsection{Saran}

DOI: $10.52362 /$ jisicom.v5i1.384

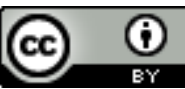

Ciptaan disebarluaskan di bawahLisensi Creative Commons Atribusi 4.0 Internasional. 
Journal of Information System, Informatics and Computing

Website/URL: http://journal.stmikjayakarta.ac.id/index.php/iisicom

Email: jisicom@stmikjayakarta.ac.id, jisicom2017@gmail.com

Dari hasil penulisan skripsi yang penulis lakukan pada Perpustakaan Keliling Suku Dinas Perpustakaan dan Kearsipan Kota Administrasi Jakarta Utara, penulis ingin memberikan saran yang kiranya dapat berguna bagi Perpustakaan Keliling Suku Dinas Perpustakaan dan Kearsipan Kota Administrasi Jakarta Utara terutama pada Sistem Informasi Perpustakaan keliling.

1. Untuk melengkapi suatu sistem menjadi perancangan sistem diperlukan sarana pendukung seperti perangkat keras dan perangkat lunak. Dengan sarana pendukung yang sesuai dengan sistem yang diinginkan maka perancangan sistem informasi akan berjalan dengan baik dan lancar.

2. Pemberian batasan wewenang penggunaan aplikasi program kepada menjaga keakuratan data-data yang tersimpan pada database agar tidak dapat dipertanggung jawabkan.

setiap user harus diberikan, untuk tidak terjadi manipulasi data yang

diharapkan dapat mengembangkan sistem informasi yang ada ketahap pengembangan android dengan memanfaatkan teknologi informasi saat ini agar dapat mudah digunakan anggota dalam melakukan pengechekan buku, pinjaman buku, pengembalian buku, dan baca online diluar lingkungan perpustakaan, sehingga dapat mempermudah para pelaku sistemnya dalam menjalankan system.

\section{REFERENSI}

[1] Anggraeni, E. Y., \& Irviani, R. (2017). Pengantar Sistem Informasi. Yogyakarta: Andi Offset.

[2] Chan, S. (2017). Membuat aplikasi Database dengan PowerBuilder 12.6 dan MySQL. Jakarta.

[3] Mundzir MF (2018). Buku Sakti Pemograman Web seri PHP. Yogyakarta: START UP.

[4] Rosa A. S dan M. Shalahudin. (2018). Rekayasa Perangkat Lunak. Bandung: Informatika.

[5] Rohi Abdulloh (2018). 7 IN 1 Pemrograman Web untuk Pemula. Jakarta: PT Elex Media Komputindo.

[6] Sukamto, R. A., \& Shalahuddin, M. (2018). Rekayasa Perangkat Lunak Terstruktur dan Berorientasi Objek (edisi revisi). Bandung: Informatika.

[7] Sutarno, NS. 2006. Perpustakaan dan Masyarakat. Jakarta: Yayasan Obor Indonesia.

[8] ___ "Pengertian MySQL" http://www.scribd.com/doc/57726016/18/Pengertian-MySQL/ (diakses tanggal 2 Maret 2020) "Relasi Tabel"

[9] ___ http://www.scribd.com/doc/54052219/Internet-Merupakan-Jaringan-Global-Komputer-Dunia di akses pada tanggal 22 Maret 2020

[10] Nur Aini dkk "Pembangunan Sistem Informasi Perpustakaan Berbasis Web menggunakan Metode Rapid Application Development (RAD) (Studi pada : SMK Negeri 11 Malang)"

[11] Nurul Alifah Rahmawat dkk "Analisis dan perancangan desain sistem informasi perpustakaan sekolah berdasarkan kebutuhan sistem"

[12] Muhammad Husni Rifqo, dkk Jurnal "Implementasi Algoritma Backtracking Dalam sistem informasi perpustakaan untuk pencarian judul buku (studi kasus unit pelayanan terpadu perpustakaan universitas muhammadiyah bengkulu)"

[13] Yayasan Pengembangan Perpustakaan Indonesia, Pengertian, Tujuan dan Fungsi Perpustakaan Keliling,diakses melalui situs: (http://www.pustakaindonesia.org/2011/04/09/pengertian-tujuan-dan-fungsi-perpustakaankeliling/) pada Tanggal 26 Oktober 2020.

[14] Anis Rohmadi, Verdi Yasin (2020) “Desain Dan Penerapan Website Tata Kelola Percetakan Pada CV Apicdesign Kreasindo Jakarta Dengan Metode Prototyping”, Journal of Information System, Informatics and Computing. http://journal.stmikjayakarta.ac.id/index.php/jisicom/article/view/210 E-ISSN: 2597-3673 (Online), P-ISSN: 2579-5201 (Print) Vol. 4 No.1, June 22, 2020. Pp.70-85

[15] Septian Cahyadi, Verdi Yasin, Mohammad Narji, Anton Zulkarnain Sianipar (2020) "Perancangan Sistem Informasi Pengiriman Dan Penerimaan Soal Ujian Berbasis Web ( Studi Kasus: Fakultas Komputer Universitas Bung Karno)", Journal of Information System, Informatics and Computing.

DOI: $10.52362 /$ jisicom.v5i1.384

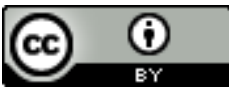

Ciptaan disebarluaskan di bawahLisensi Creative Commons Atribusi 4.0 Internasional. 
e-ISSN : 2597-3673 (Online) , p-ISSN : 2579-5201 (Printed)

Vol.5 No.1, Juni 2021

Journal of Information System, Informatics and Computing

Website/URL: http://journal.stmikjayakarta.ac.id/index.php/jisicom

Email: jisicom@stmikjayakarta.ac.id , jisicom2017@gmail.com

http://journal.stmikjayakarta.ac.id/index.php/jisicom/article/view/199 E-ISSN: 2597-3673 (Online), P-ISSN: 2579-5201 (Print) Vol. 4 No.1, June 22, 2020. Pp.1-16

[16] Ifan Junaedi, Ndaru Nuswantari, Verdi Yasin (2019) “Perancangan Dan Implementasi Algoritma C4.5 Untuk Data Mining Analisis Tingkat Risiko Kematian Neonatum Pada Bayi", Journal of Information System, Informatics and Computing. http://journal.stmikjayakarta.ac.id/index.php/jisicom/article/view/203 E-ISSN: 2597-3673 (Online), P-ISSN: $2579-5201$ (Print) Vol. 3 No.1, February 13, 2019. Pp.29-44.

[17] Verdi Yasin, Anindra Ramdhan Nugraha, Muhammad Zarlis, Ifan Junaedi (2018) "Smart System Of Fast Internet Access Development Using Backbone Network Method", Journal of Information System, Informatics and Computing. http://journal.stmikjayakarta.ac.id/index.php/jisicom/article/view/198 E-ISSN: 2597-3673 (Online), P-ISSN: 2579-5201 (Print) Vol. 2 No. 2, December 31, 2018. Pp.26-34.

[18] Ito Riris Immasari, Verdi Yasin (2019) "Penggunaan Metode Analytic Hierarchy Process Untuk Menganalisis Faktor-Faktor Yang Mempengaruhi Pemilihan Calon Legislatif Di Dprd li Kota Tangerang", Journal of Information System, Informatics and Computing.

http://journal.stmikjayakarta.ac.id/index.php/jisicom/article/view/139 E-ISSN: 2597-3673 (Online), P-ISSN: 2579-5201 (Print) Vol. 3 No. 2, December 10, 2019. Pp.53-58.

[19] Verdi Yasin, Muhammad Zarlis, Tulus, Erna Budhiarti Nababan, Poltak Sihombing (2019) “Rancangan Miniatur Otomatisasi Bel Listrik Pada Gerbang Pintu Menggunakan Microkontroler Atmega8535", Journal of Information System, Informatics and Computing. http://journal.stmikjayakarta.ac.id/index.php/jisicom/article/view/68 E-ISSN: 2597-3673 (Online), P-ISSN: 2579-5201 (Print) Vol. 3 No. 1, February 13, 2019. Pp.13-20.

[20] Anggeri S. Nurjaman, Verdi Yasin (2020) “Konsep Desain Aplikasi Sistem Manajemen Kepegawaian Berbasis Web Pada PT. Bintang Komunikasi Utama ", Journal of Information System, Informatics and Computing. http://journal.stmikjayakarta.ac.id/index.php/iisicom/article/view/363 E-ISSN: 2597-3673 (Online), P-ISSN: 2579-5201 (Print) Vol. 4 No. 2, December 28, 2020. Pp.143-174.

[21] Verdi Yasin, Azhar Ahmad Riza, Rumadi Hartawan (2017) “Pengembangan Aplikasi Pemulihan Layanan Bencana Sistem Informasi Peneriman Negara Bukan Pajak Online Di Lingkungan Kementerian Keuangan Republik Indonesia", Journal of Information System, Informatics and Computing.

http://journal.stmikjayakarta.ac.id/index.php/jisicom/article/view/4 E-ISSN: 2597-3673 (Online), P-ISSN: 2579-5201 (Print) Vol. 1 No. 1, September 20, 2017. Pp.33-56.

DOI: $10.52362 /$ jisicom.v5i1.384

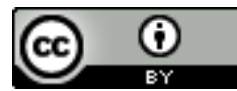

Ciptaan disebarluaskan di bawahLisensi Creative Commons Atribusi 4.0 Internasional. 